\title{
PROPERTY AND THE POLITICS OF DISTRUST
}

\section{Property, Speech, and the Politics of Distrust}

\author{
Richard A. Epstein †
}

\section{Property and Speech: Constitutional Opposites or Constitutional Twins?}

My task in this article is not an enviable one: It is to persuade you that the dominant mode of thinking about property rights during the past fifty years has been a mistake of constitutional dimensions. It would be convenient if I could say that I merely favor a return to the set of doctrines that governed economic liberty and property before 1937, in the so-called Lochner era. ${ }^{1}$ Yet that description would understate the difference between my views

† James Parker Hall Distinguished Service Professor of Law, The University of Chicago. This Article was prepared for The Bill of Rights in the Welfare State: A Bicentennial Symposium, held at The University of Chicago Law School on October 25-26, 1991, in a debate with Professor Frank I. Michelman of Harvard University, to whose work on eminent domain I continue to be heavily indebted. I should like to thank Elena Kagan, Lawrence L. Lessig, Michael W. McConnell, Daniel Shapiro, and Geoffrey R. Stone for their valuable comments on an earlier draft of this Article. I have also benefitted from the comments I received when I presented versions of this paper at a faculty seminar at the Institute of Humanities at Dartmouth College, and at a lecture at the Vermont Law School in November, 1991.

1 The era is, of course, named after Lochner v New York, 198 US 45 (1905). For a leading attack on the case, see Cass R. Sunstein, Lochner's Legacy, 87 Colum L Rev 873 (1987). In truth, before 1937, courts routinely upheld economic regulations that deviated dramatically from common law principles, of which rent control statutes are only the most conspicuous examples. See New York Central R.R. Co. v White, 243 US 188 (1917) (upholding the constitutionality of New York's workmen's compensation act). For a discussion of the manifest inconsistencies in those decisions supposedly protective of economic liberties, see Richard A. Epstein, The Mistakes of 1937, 11 Geo Mason U L Rev 5, 13-20 (Winter 1988). 
and the historical evolution of the law. Some of the most restrictive decisions on property rights took place in the years before 1937 , often by judges who would be described as conservative by modern standards. I refer here by way of example to the lamentable decisions of Justice Holmes in Block v Hirsh, ${ }^{2}$ and of Justice Sutherland in Euclid $v$ Ambler Realty $\mathrm{Co}^{3}$ The first of these upheld the power of the state to impose rent control restrictions, "temporarily" of course; and the second gave the state expansive powers to control land use through zoning, ${ }^{5}$ a power that has hardly been enlarged in the ensuing sixty years of ceaseless litigation.

I am therefore urging not a return to some lost golden era, but the adoption of a regime for the protection of private property and economic liberties that is far more extensive and internally coherent than the patchwork of protections afforded to these interests under the Takings Clause before 1937. More difficult still, I believe that all this transformation is possible even with the universal acceptance of the "welfare state"-the commitment to support people in need by casting that burden on others through the coercive mechanism of the state-which has become a permanent part of the basic constitutional order at both the state and federal level. My task is made more complicated in that the defense of the present constitutional scheme is undertaken by Professor Frank Michelman, who surely ranks among the most eloquent expositors of the Just Compensation Clause, and as one of the most ardent defenders of the modern legal order that I seek to undermine. ${ }^{6}$

In order to develop my case, I shall pursue the analysis from an unconventional quarter: I shall look at the doctrinal structures of First Amendment law and then indicate how they can, and should, be carried over into the analysis and discussion of the Takings Clause. My basic conclusion is that the Takings Clause and economic liberties should not be viewed as things alien and uncongenial to modern constitutional norms. One need only apply to pri-

2256 US 135 (1921). I have criticized Holmes's Block opinion in Richard A. Epstein, Takings: Private Property and the Power of Eminent Domain 176-77 (Harvard, 1985) ("Takings"); and in Richard A. Epstein, Rent Control and the Theory of Efficient Regulation, 54 Brooklyn L Rev 741, 748-50 (1988).

${ }^{3} 272$ US 365 (1926). I have also criticized Sutherland's Euclid opinion in Epstein, Takings at 131-34 (cited in note 2).

4 Block, 256 US at 154.

- Euclid, 272 US at 388-90.

${ }^{6}$ See Frank I. Michelman, Property, Utility, and Fairness: Comments on the Ethical Foundations of "Just Compensation" Law, 80 Harv L Rev 1165 (1967), an acknowledged classic in the area. 
vate property the presuppositions and techniques that have organized the law of freedom of speech. Within this framework the sole concession that one must make to the welfare state is to accept income redistribution funded with taxes (perhaps even progressive taxes) derived from general revenue sources. Otherwise, the edifice to protect freedom of speech carries over to private property, without losing a beat.

In comparing amendments, there is a genuine question as to which body of First Amendment law one should consult. The obvious point of departure is the body of case law developed by the United States Supreme Court. That is, of course, an incredibly complicated body of law, with many nuances that are not necessarily relevant to the present discussion. ${ }^{7}$ More critically to this enterprise, it may well contain certain serious mistakes of both under- and over-protection of speech that can embarrass any general theory.

Some of the free speech decisions are simply wrong in principle. For example, New York Times Co. $v$ Sullivan ${ }^{8}$ protects speech more than a comprehensive theory of speech requires. ${ }^{9}$ In the opposite direction, of course, a consistent theory also requires more extensive protection of speech than the Court now provides. ${ }^{10}$

Other free speech decisions, though sound in principle, incorrectly apply the principle to the case at hand. One conspicuous illustration is perhaps United States $v$ O'Brien, ${ }^{11}$ where the Supreme Court upheld the conviction of the defendant for burning his draft card, in violation of a content-neutral statute that forbade the willful destruction of draft cards for any purpose. ${ }^{12}$ The Court announced that it followed a test of compelling state interest, which I regard as sound law. ${ }^{13}$ But the Court then so watered down its application as to allow the weakest forms of administra-

T For one recent account, see Geoffrey R. Stone, et al, Constitutional Law 1011-454 (Little Brown, 2d ed 1991).

376 US 254 (1964).

- See Richard A. Epstein, Was New York Times v. Sullivan Wrong?, 53 U Chi L Rev 782 (1986). See also text accompanying notes 66-70.

${ }^{10}$ See text accompanying notes $93-95$.

12391 US 367 (1968).

12 Id at 382 .

${ }^{13}$ The relevant portion of the opinion reads:

To characterize the quality of the governmental interest which must appear, the Court has employed a variety of descriptive terms: compelling; substantial; subordinating; paramount; cogent; strong. Whatever imprecision inheres in these terms, we think it clear that a government regulation is sufficiently justified if it is within the constitutional power of the Government; if it furthers an important or substantial governmental interest; if the governmental interest is unrelated to the suppression of free expres- 
tive convenience-communication with draftees, reminders of civic obligations-to count as compelling state interests. ${ }^{14}$

A similar debasement of the compelling state interest test is apparent in Austin $v$ Michigan State Chamber of Commerce. ${ }^{15}$ There the Court found a compelling state interest that allowed Michigan to prohibit corporations from making independent expenditures to support or oppose candidates for state elective office. The Court's inquiry on the question of state justification was, however, wholly disingenuous, for the Court contented itself with unsupported assertions that corporate contributions were "corrosive and distorting" of the overall level of political debates. ${ }^{16}$ But there was no effort to offer any account of those rough and tumble political debates which were uncorrupted and undistorted. Nor was there the slightest recognition that different corporations might weigh in on different sides of election campaigns, or that political expenditures by corporations might be especially valuable precisely because corporations (and their out-of-state shareholders) could not vote in elections whose outcome is of major importance to them. It is difficult to see how any selective restriction on the parties entitled to engage in political speech should survive a First Amendment challenge.

I regard it, however, as mistaken to allow the covert dilutions of the compelling state interest test in either O'Brien or Austin to organize any comparison between First and Fifth Amendment law. Even after these decisions, it is possible to make sensible internal adjustments and reevaluations of First Amendment law to facilitate the appropriate comparisons. ${ }^{17}$ Basically, the "corrections" that one must make to speech law for the analysis to be good must satisfy two conditions: First, they cannot be so numerous that they completely revise First Amendment law, and second, they must accord with the doctrine's accepted animating principles.

Finally, there is a third limitation with respect to the kinds of issues that I consider. Generally stated, both the First and Fifth

sion; and if the incidental restriction on alleged First Amendment freedoms is no greater than is essential to the furtherance of that interest.

Id at 376-77 (footnotes omitted).

14 Id at $378-90$.

15 494 US 652 (1990). For trenchant criticism, see Jill E. Fisch, Frankenstein's Monster Hits the Campaign Trail: An Approach to Regulation of Corporate Political Expenditures, $32 \mathrm{Wm}$ \& Mary L Rev 587 (1991).

16 Austin, 494 US at 660.

17 For an example of such reevaluation of O'Brien, see Dean Alfange, Jr., Free Speech and Symbolic Conduct: The Draft-Card Burning Case, 1968 S Ct Rev 1, 23-27, 42-46. 
Amendments can apply to two distinct types of situations. In the first, the government seeks to regulate the private activities of individuals on their own property. ${ }^{18}$ The activity could be a political meeting, or the construction of a new home. In the second, the government seeks to regulate activities on public property. ${ }^{19}$ Thus the issue is how the government can allocate "its" own resources through contract or through grant. Typically the issue is what conditions the government may attach to its permission to use public space or to receive public funding. Sometimes the question is whether the government can condition a tax benefit upon the performance of some particular act or the making of some particular statement. ${ }^{20}$ These latter issues are of increasing importance in modern times, and in many cases where the government acts as a contracting party, I think that the law is less protective of both speech and property than it should be. ${ }^{21}$ Nonetheless the exclusive focus in this Article shall be on the role of government as regulator, not as contracting party, funding agent, or property owner.

With these caveats in mind, it is critical to understand the basic attitude that courts take toward the legislative and executive branches of government. Whatever the virtues of stirring rhetoric, it is clear that the First Amendment cannot prohibit all regulation of speech by all government at all levels. Freedom of speech is not the same as an uninhibited license to speak-to lie, to deceive, to molest, to coerce. So the fundamental postulate of distrust of government does not translate into a total ban against all government regulation of all forms of speech, but into a strong presumption that can be overridden only by establishing some compelling government interest, as the language used in O'Brien and Austin itself indicated. The key questions therefore under the First Amendment-and they are also the key questions under the Fifth

${ }^{18}$ See, for example, Nollan v California Coastal Commission, 483 US 825 (1987) (Commission granted a permit allowing construction of a larger house on beachfront property on the condition that the property owners grant the public an easement across their private beach).

${ }^{19}$ See, for example, Lovell $v$ City of Griffin, 303 US 444 (1938) (permit required to distribute circulars within the city limits); Red Lion Broadcasting Co. v FCC, 395 US 367 (1969) (FCC requirement that each side of a public issue be presented on broadcast stations; the "fairness doctrine").

${ }^{20}$ See, for example, Speiser v Randall, 357 US 513 (1958) (veteran's tax exemption conditioned on filing of an oath that taxpayer did not advocate overthrow of the United States or California governments, nor advocate support of a hostile government during wartime).

${ }^{21}$ For a statement of my views, see Richard A. Epstein, Foreword: Unconstitutional Conditions, State Power, and the Limits of Consent, 102 Harv L Rev 4 (1988). 
Amendment-are the following: First, what is the scope of the initial protection afforded by the presumption in favor of free speech? Second, how can that protection be overridden?

This inquiry, even within a strict interpretative framework, is necessarily vast. No analysis of what is meant by speech alone will determine the contours of freedom of speech. Instead it is necessary to detail the operations of a system of freedom, a vast undertaking that reluctant judges undertake only because they labor under the strict compulsion to decide cases. But scholars can and must be more relentless and systematic in their pursuits. The basic outlines of a system of freedom of speech must be delineated and defended. But the size of the payoff is commensurate with the difficulty of the undertaking. If we understand how this body of law works, then we will have a good road map for understanding the Takings Clause.

There are, of course, important differences between the Free Speech and Takings Clauses. The Free Speech Clause does not contain a Just Compensation Clause ("Congress may abridge freedom of speech for public use, with just compensation"), ${ }^{22}$ and it is possible to protect freedom of speech without at all confronting what is critical about economic affairs in the welfare state: the redistribution of wealth on the basis of need. But before distinguishing property from speech, it is important to see what general view links them together. The modern insistence that speech is a fundamental liberty, while property is the creature of legislation and subject to its whims, does much to distort the proper relationship between the two sets of constitutional limitations. The Free Speech and Takings Clauses should be understood as working in harmony with each other, not in opposition. It is important therefore never to forget the essentially libertarian cast to both clauses: strong, decentralized private rights and a central government with limited powers, any exercise of which must be justified.

In this Article I shall outline the basic linkage between these two clauses in order to demonstrate that what has proved sound policy for speech should pay handsome social dividends for property and economic affairs as well. Indeed, there is good reason to believe that free speech will produce more net social benefit in a world in which property rights are more carefully protected than under the present state of affairs, where there is essentially no con-

${ }^{22}$ Compare US Const, Amend I ("Congress shall make no law . . . abridging the freedom of speech ...."), with US Const, Amend V ("[N]or shall private property be taken for public use without just compensation."). 
stitutional protection of property and contract against prospective legislation, or, it now appears, against retroactive legislation as well. $^{23}$ In order to make this case, I shall explicate the dominant tendencies of First Amendment law through the eyes of a cautious libertarian, and then show how the parallel issues for property are usually resolved in a very different fashion.

The plan of action is therefore as follows. In Section II, I argue that the constitutional defenses of property and speech rest on the sense that government is a necessary evil. Government is necessary to preserve civil order, but its officials should not be viewed as saviors; they are self-interested persons with imperfect knowledge subject to a universal presumption of distrust.

In Section III, I identify the extensive set of issues common to freedom of speech and to the protection of private property. I show how the postulate of distrust organizes First Amendment doctrine, and how its absence explains the flaccid and unprincipled structure of the law protecting private property and economic liberties. The points of parallelism are made evident by the logical structure of the two clauses. Both clauses set initial presumptions, and not final absolutes. In both areas, therefore, the complete inquiry requires at least five stages: (1) identifying the protected private interest; (2) identifying the state actions that violate that interest; (3) justifying those state actions, if possible; (4) timing the remedy to protect the private interest; and (5) determining whether to force an exchange to curtail that interest.

Finally, in Section IV, I explain how the logical structure of the First Amendment can be carried over to deal with economic liberties, even granting the unassailable first premise of the welfare state-some form of income and wealth distribution in favor of the poor.

\section{The Logic of Distrust}

It is perhaps useful to begin with a point that can be lost in the more abstract discussion of constitutional theory that follows. There is, of course, both a Free Speech Clause and a Takings Clause (one that contains explicit reference to "private property"), and the extensive interpretive enterprise that follows is an effort to make sense of the two texts in the wide range of situations to which they apply. To begin, however, I do not want to concentrate

\footnotetext{
${ }^{23}$ See, for example, Usery o Turner-Elkhorn Mining Co., 428 US 1 (1976) (constitutionality of retroactive taxes to fund black lung disease compensation plans).
} 
on specific textual difficulties, but on a second aspect of constitutional interpretation of equal dignity with the first: the basic attitudes toward government that are brought to the interpretation of a particular text. Under the First Amendment that attitude clearly is, or has to be, an attitude of distrust. ${ }^{24}$

I do not have in mind any very narrow or technical meaning of distrust. As a matter of hornbook law, the person who receives a friend's money, which she then converts to her own use, is a person who has abused a trust. By like analogy, the person who receives public money, which she then spends for private purposes, has abused a trust as well. In each case, a person stands in a position whereby she can obtain personal gain at the expense of individuals to whom she owes a duty. In other cases, the idea of distrust has to do with favoritism: benefits are given to $\mathrm{A}$ that are denied to $\mathrm{B}$; when their roles are reversed, some other "neutral" principle of decision is employed to make sure that $A$ prevails again, for reasons utterly irrelevant to any public purpose. The postulate of distrust holds that persons with a public interest to protect and a political agenda to advance will be willing-across the board-to sacrifice the former in order to advance the latter.

In putting the concern in this particular fashion, the idea of distrust is a universal solvent that can be brought to bear on any political initiative. Distrust has both ancient lineage and modern application: "Quis custodiet custodies?" ("Who guards the guardians?") is a Latin maxim that has lost none of its vitality in its contemporary setting. By the same token, distrust is not tied to any narrow or partisan political agenda: Democrat or Republican, liberal or conservative, are equally capable of abusing the public trust. The themes of self-dealing, of waste, of corruption, which are obvious corollaries to the concern with distrust, should also resonate across the usual political lines of controversy. The point is not that all statutes and all government actions are worthy of distrust, for some genuine public interest statutes (think of the Statute of

24 See, for example, Vincent Blasi, The Checking Value in First Amendment Theory, 1977 Am Bar Found Res J 521. In particular, Blasi notes:

One basic value seems highly relevant to these newer claims [for First Amendment protection], yet has not been accorded a central place in our articulated theory of the First Amendment. This is the value that free speech, a free press, and free assembly can serve in checking the abuse of power by public officials.

Id at 527. I will address some of the other values later. It is sufficient to note here that the list of four values announced by Thomas I. Emerson, The System of Freedom of Expression 6-7 (Random House, 1970), does not contain the checking value. See text accompanying note 31 . 
Frauds and the standard statute of limitation) can emerge from the political process. Yet, at the very least, distrust alerts us to the constant temptation facing any public official who is entrusted with extensive power, but who is all too often subject to only limited supervision.

This theme of distrust, suitably qualified, is not only central to political theory; it is also central to any reading of our constitutional heritage. When Madison wrote that "Enlightened statesmen will not always be at the helm," ${ }^{25}$ it was clear that he thought that diversion of public wealth and position for private gain was the central problem that government must face. The force of his remark is only confirmed by looking at the motley collection of public officials holding high office today. Similarly, Madison's discussion of the entire structure of federalism, divided government, and the system of checks and balances at the federal level shows that the theme of distrust has worked itself into the warp and woof of our constitutional structure.

The protection of speech (which is limited to protection against actions by Congress), and the protection of property (which, if anything, is more comprehensive ${ }^{26}$ ) should be read in light of these political concerns. All too often the desire of political figures to suppress speech has to be understood as a crude effort to suppress criticism of public actors, which could lead to their deserved political embarrassment, removal from office, or electoral defeat. Thus the social good of free speech is found in the fundamental check it exerts on how government officials behave. ${ }^{27}$ Harry Kalven, while no public choice theorist, was right to stress the importance of seditious libel as the central lesson of the First Amendment-the need to fear government misconduct. ${ }^{28} \mathrm{~A}$ complex set of

${ }^{25}$ See Federalist 10 (Madison) in Clinton Rossiter, ed, The Federalist Papers 77, 80 (Mentor, 1961) ("It is in vain to say that enlightened statesmen will be able to adjust these clashing interests and render them all subservient to the public good. Enlightened statesmen will not always be at the helm.").

${ }^{26}$ Compare US Const, Amend I ("Congress shall make no law ... abridging the freedom of speech ...."), with US Const, Amend V ("[N]or shall private property be taken for public use with just compensation."). The passive voice of the Fifth Amendment does not expressly limit the Fifth Amendment protection to laws passed by Congress.

${ }_{27}$ See Blasi, 1977 Am Bar Found Res J at 529-38 (cited in note 24), for the antecedents in Locke and Madison.

${ }^{28}$ See Harry Kalven, Jr., The New York Times Case: A Note on "The Central Meaning of the First Amendment", $1964 \mathrm{~S}$ Ct Rev 191, 205 ("[A]nalysis of free-speech issues should hereafter begin with the significant issue of seditious libel and defamation of government by its critics rather than with the sterile example of a man falsely yelling fire in a crowded theatre."). Kalven may have been correct about the example, but he was wrong about the tradition. Holmes used the example of crying fire in order to show why the free- 
doctrines for both content regulation and content-neutral regulation has grown up out of this fear of government misconduct. ${ }^{29}$ This fear, while strongest for political speech, ${ }^{30}$ surely extends to manifold other forms of artistic and literary expression as well.

\section{A. Distrust: A Single Rationale for Speech and Takings Law}

This effort to locate a single concern behind the First Amendment is at variance with the common intellectual practice, which insists that there are many separate "value bases" that lie behind the interpretation of any given constitutional provision. The dominant modes of modern interpretation are far too ecumenical: They try to find a broad collection of values to justify the key constitutional provisions, and then pick that rule which best accommodates those competing values. Thus Professor Emerson's list for free speech, which has achieved the status of conventional wisdom, includes individual self-fulfillment, the pursuit of truth in the marketplace of ideas, participation in public life, and the maintenance of a stable community through interaction and exchange. ${ }^{31}$

I am instinctively and deeply suspicious of explanations that rely on a combination of many independent factors to generate the doctrinal structure of any area of law. The objection is formal. Two values can either cut in the same direction or in different directions. If they cut in the same direction, then it is not possible to choose between them. If they cut in different directions, then any outcome can be achieved by assigning the right weight to the preferred value. The uneasiness that many commentators have had with "balancing tests" under the First Amendment is not only because of the practical indeterminacy of such tests, but also because of their theoretical malleability: When no single variable is to be maximized, then any solution is as good as any other. We should have the same suspicion of these loose tests under the Takings

dom of speech was not an absolute. See Schenck v United States, 249 US 47, 52 (1919). But the early cases testing the limitations on speech were all concerned with seditious activities and national security. Schenck itself involved pamphlets urging resistance to the draft. See id at 50-51.

29 For exhaustive and sympathetic expositions of the basic positions, see Geoffrey $R$. Stone, Content Regulation and the First Amendment, 25 Wm \& Mary L Rev 189 (1983); Geoffrey R. Stone, Content-Neutral Restrictions, 54 U Chi L Rev 46 (1987).

30 Compare Cass R. Sunstein, Free Speech Now, 59 U Chi L Rev 255, 262-63, 301 (1992) (First Amendment principally protects political speech).

${ }^{31}$ Emerson, The System of Freedom of Expression at 6-8 (cited in note 24). 
Clause, where the plastic nature of the doctrine is evident upon the slightest inspection. ${ }^{32}$

It is important therefore to recognize that there is weakness and not strength in the common effort to find plural bases for speech and takings law. ${ }^{33}$ In order to show that such strategies are not appropriate, I make just two assumptions: first, that legislators and executives always have perfect knowledge, and second, that they always seek to serve the public good. On these assumptions, I argue, even if the First and Fifth Amendments were given the most stringent interpretations imaginable, every statute would be constitutional under the most stringent standards of judicial review. ${ }^{34}$

\section{Distrust and the Takings Clause.}

To demonstrate, let us begin with the Takings Clause. What kinds of economic legislation should we expect the legislature to pass if it had perfect knowledge and perfect motivation? In the first place, we should expect that each and every statute would expand the total size of the economic pie. There would be no reason for the legislature to adopt any rule that would cost the losers more than it would provide to the winners. The allocative losses involved are losses that are imposed on someone, and a legislature with perfect knowledge would know that these losses exist, and one with perfect motivation would never wish to inflict them gratuitously. Instead the legislature would adopt only those proposals that produced a net benefit for the citizenry at large. Markets would be allowed to operate where they functioned well; where they did not, they would only be restrained by the best possible system of legislation.

Thus the first consequence of this system is that each public transaction would produce a net social gain; that is, the legislature would achieve Kaldor-Hicks optimality. ${ }^{35}$ The Takings Clause, however, is concerned not only with the size of the gain, but also

${ }^{32}$ I pursue this theme in Richard A. Epstein, Not Deference, But Doctrine: The Eminent Domain Clause, $1982 \mathrm{~S}$ Ct Rev 351.

${ }^{33}$ For the opposite conclusion, as applied to takings, see Stephen R. Munzer, $A$ Theory of Property ch 11 (Cambridge, 1990).

34 I have developed this argument with respect to the Takings Clause in Richard A. Epstein, The Utilitarian Foundations of Natural Law, 12 Harv J L \& Pub Pol 713, 745-47 (1989).

${ }^{35}$ Under the Kaldor-Hicks standard of optimality, a transaction is judged to be efficient only if it produces a net gain, whether or not it improves the economic position of each individual party to the transaction. 
with its distribution. It is designed to ensure that any allocative improvements introduced by the legislature do not suffer from attendant distributive dislocations. In other words, the Just Compensation Clause contemplates the Pareto standard of optimality, ${ }^{36}$ not the Kaldor-Hicks standard. ${ }^{37}$

But if the legislature is knowledgeable and benevolent, it will also make the right allocative decision in every case; it will achieve Pareto optimality as well. Even if there are losers under one statute, it is likely that they will be the winners in the next, for the benevolent legislature will not favor one class of citizens over another. As the number of contexts in which legislation is passed increases, the odds that any person will be a net loser over the full set of transactions is reduced asymptotically to zero. ${ }^{38}$ Given that the winners and losers in each case are randomly selected from the whole, it follows that there is no need for the winners to compensate the losers in any individual transaction. It also follows that the legislature will not even have to pay the administrative costs of calculating losses and gains in each case: It knows it will achieve Pareto optimality over time and across statutes, and so it can dispense with the entire process of valuation and side payments.

The motivation for the Takings Clause must come from a fear that the legislature has imperfect knowledge, imperfect motives, or both. The power to coerce is enormous, and there is the risk that it will be used to benefit those who possess it at the cost of those who suffer from it. One reason to dislike theft is that it has the tendency to move goods from high to low value uses with positive administrative costs. The same dangers inhere in legislation under a system of majority rule. The Just Compensation Clause requires payment for the taking as a means of disciplining the legislature. If the legislature can afford to pay when it takes, then the fact of compensation itself gives some reason to believe in the net social gain. The clause therefore is designed to prevent allocative losses through collective action, and that problem only arises if the legislature has imperfect knowledge or imperfect motivations. Without legislative abuse, there would be no need to insist upon compensation.

\footnotetext{
${ }^{36}$ Under the Pareto standard of optimality, a transaction is judged to be efficient if it improves, or at least does not worsen, the economic position of each individual party to the transaction.

${ }^{37}$ Thus a transaction which achieves Kaldor-Hicks optimality, but which worsens the economic position of one or more parties to the transaction, can only achieve Pareto optimality if the winners then compensate the losers.

${ }^{38}$ See Epstein, 12 Harv J L \& Pub Pol at 746 \& n 60 (cited in note 34).
} 
On the other side of the coin, the Just Compensation Clause also eliminates the need for the judiciary to compare what the public gains from the statute with what the individual property owner loses. The danger of legislative abuse invites judicial oversight of the legislature. A compensation test thus becomes necessary in order to reduce the otherwise horrendous pressures on the judicial system to sort out which government interventions are justified and which are not. But the courts have access to little information about what kinds of transactions benefit the public, and, by definition, cannot trust any information on that score provided by the state. On the other hand, the courts can get tolerable measures of individual losses in a wide range of cases, or can find some structural reason in the even distribution of benefits and burdens ${ }^{39}$ to obviate the need for direct measurement of public benefit in each case. The constitutional articulation of a just compensation standard is not equivalent to a "taking with good cause" standard. It is invoked not only to secure justice to the individual, but also to combat the untrustworthiness of government officials.

\section{Distrust and the Free Speech Clause.}

The analysis of distrust under the First Amendment is similar. It is often said that the First Amendment is designed to serve other values: to encourage participation in good government; to ensure that a diversity of viewpoints are expressed; to enable personal self-realization. ${ }^{40}$ The control of legislative abuse is thought to be only one value among many, and a late entry into the pantheon at that.

But again suppose that there were no fear of abuse, so that the legislature passed speech laws with perfect knowledge and benevolent motives. Why then the concern? The ideal legislature would be as concerned with individual self-realization as any court, and it would better know how to achieve it. If collective support for speech were necessary, the legislature would provide the proper subsidies to the proper persons in the proper amounts. It would promote the necessary diversity of opinions and provide the information necessary to facilitate good individual choices. But, if restrictions on speech were necessary to facilitate the right choices, the legislature would also provide them. Quite simply, the good

\footnotetext{
39 See the discussion of disproportionate impact tests in Epstein, Takings at 204-09 (cited in note 2).

to See text accompanying note 31 .
} 
and knowledgeable legislature wants what the learned scholars of constitutional law want. If we had no cause to distrust the legislature, then we could dispense with the costly and inconvenient apparatus of judicial review of the First Amendment, and could rely upon Meiklejohn's good citizens to reach the right result every time. ${ }^{41}$ His version of the "good man" calls for a celebration of free speech, but gives no reason why speech needs or should receive constitutional protection.

Yet we do not take Meiklejohn's carefree attitude, and abuse of public office is the only reason for political aspiration to be transferred into constitutional protection. From virtuous legislators there is little to fear, and it is doubtful that the First Amendment will constrain them in any meaningful way. But bad legislators in power have a tendency to stay in power. Just as they will steal, there is a risk that they will stifle criticism, rig debate, and disseminate falsehoods to achieve their ends. It is to them, or to their control, that the First Amendment is dedicated.

But why trust the judges, who are subject to imperfections of their own? The answer is that there is no system of perfect control, and judicial review is simply part of the better overall strategy to curb abuse. The reason is that judicial review is another mechanism that provides for a division of power. With judicial review in place, any piece of legislation has to clear an additional hurdle-which is good, because the presumption of distrust translates into the belief that more rather than less legislation is the greater danger. But there should be no illusion: If all branches of govern-

"See Alexander Meiklejohn, Political Freedom: The Constitutional Powers of the People (Harper, 1960) (originally published in 1948). As Vincent Blasi has noted, Meiklejohn's participation theory treats government as a large town meeting, composed of virtuous citizens who participate for the common good. Blasi, $1977 \mathrm{Am} \mathrm{Bar}$ Found Res $J$ at 554-67 (cited in note 24). Meiklejohn's virtuous citizen is the antithesis of the "bad man" of whom Holmes wrote in Oliver Wendell Holmes, Jr., The Path of the Law, 10 Harv L Rev 457 (1897). Of Holmes, Meiklejohn said:

As against the dogma of Mr. Holmes I would venture to assert the counterdogma that one cannot understand the basic purposes of our Constitution as a judge or a citizen should understand them, unless one sees them as a good man, a man who, in his political activities, is not merely fighting for what, under the law, he can get, but is eagerly and generously serving the common welfare.

Blasi, 1977 Am Bar Found Res J at 557 (cited in note 24) (quoting Meiklejohn, Political Freedom at 66).

The asserted separation between the private and public self adumbrates many of the themes prominent in the republican revival of the 1980s. See, for example, Frank I. Michelman, Foreword: Traces of Self-Government, 100 Harv L Rev 4 (1986); Cass R. Sunstein, Beyond the Republican Revival, 97 Yale L J 1539 (1988). For criticism, see also Richard A. Epstein, Modern Republicanism-Or the Flight From Substance, 97 Yale L J 1633 (1988). 
ment have unsound beliefs or corrupt motives, then the additional division of power brought on by judicial review still will not alter any flawed outcomes achieved by the legislative process alone. The protection of private property and economic liberties fails today solely because no branch in our government-legislative or judicial-accords them the same weight that they had in the original constitutional scheme.

\section{B. Mutual Reinforcement of Property and Speech Rights}

In light of distrust, we should be very leery indeed of any proposals, such as those advanced recently by Owen Fiss, ${ }^{42}$ that wish to reduce the protection of freedom of speech to the paltry level now afforded economic liberties. Fiss is correct to see that the basic assumptions about the behavior of government and private offcials are as important to the interpretation of the First Amendment as they are to the Fifth. But he sadly underestimates the capacity for legislative abuse that lies in both these areas. The endless machinations of the Federal Communications Commission, a body which regulates both speech and property rights in the spectrum of broadcast frequencies, offer, it seems fair to say, no reason to believe that a system of extensive government regulation would improve the level of political discourse in this country. ${ }^{43} \mathrm{~A}$ simpler strategy that would charge the government with the enforcement of property rights, by actions against interference, is far superior to endless administrative wrangles to decide which groups should receive public subsidies for what activities.

The government necessarily holds a monopoly over force. While large private organizations may develop, their net worth is not a measure of their political power, so long as they can acquire property and influence only by consent and not by coercion. In antitrust law, the size of a firm is not evidence of its market power, and the same conclusion holds for constitutional theory. Let there be many large and powerful voices: They will not speak in unison; and in any event, they will have to pay for what they wish to say.

${ }^{42}$ See Owen M. Fiss, Free Speech and Social Structure, 71 Iowa L Rev 1405 (1986); Owen M. Fiss, Why the State?, 100 Harv L Rev 781 (1987).

${ }^{43}$ The most influential criticism of the FCC is still R.H. Coase, The Federal Communication Commission, $2 \mathrm{~J} \mathrm{~L} \&$ Econ 1 (1959). Coase's work could not have anticipated the developments of the past thirty years, during which the level of government performance has been every bit as dismal. See also Jonathan W. Emord, Freedom, Technology, and the First Amendment (Pacific Research Institute for Public Policy, 1991); Thomas W. Hazlett, The Rationality of U.S. Regulation of the Broadcast Spectrum, 33 J L \& Econ 133, 133-34 (1990). 
So long as there are secure property rights in the press (which there currently are not in broadcasting), then entry will be at low cost and many possible voices will be heard, checking influence with influence and power with power. The great mistake of socialism is to equate the risks of a rich market actor with those of the sole 'government actor. We should not repeat that mistake as a matter of modern constitutional theory.

1. Limiting factionalism through property rights.

All this is not to say that there is no danger today to our First Amendment rights. There is, but it comes from a source not usually cited. The current laws make it impossible to have well-defined property rights in anything. While possession of property may be secure against government removal, the use and disposition of virtually any asset is fair game for obstruction by the political process, whether through taxation or regulation. That political power sparks private lobbyists to petition government not only for the redress of grievances but also for partisan advantage, and legislators can demand their pound of flesh in return. ${ }^{44}$

Within this environment, more speech is not better. Freedom of speech allows factions to organize and mobilize in order to obtain wealth transfers through taxation or regulation; thus freedom of speech only reduces overall social wealth and security. The fierce battles fought by single issue political action groups of all stripes and persuasions are strong evidence of an overheated and wasteful political system in decline. It is partly for this reason that there is such a prevalent desire to control campaign expenditures, a practice which nevertheless has proved fitful and counterproductive. ${ }^{45}$

Yet here the right solution is not to restrict the liberty to speak or to lobby, given the additional risk of government abuse that would be created. It is rather to reduce the power of government to transfer wealth and dispense favors. Once the government cannot do the bidding of the interest groups who crowd its corridors, these groups will devote their efforts to more socially productive activities. The compression of the set of permissible government tasks will indirectly, but effectively, improve the level of

\footnotetext{
4t For a brief but forceful statement, see Fred S. McChesney, Rent Extraction and Rent Creation in the Economic Theory of Regulation, 16 J Legal Stud 101 (1987). The contrast between McChesney and Meiklejohn is manifest.

to See, for example, Buckley v Valeo, 424 US 1 (1976). I develop this theme further in Epstein, 97 Yale L J at 1643-45 (cited in note 41).
} 
public discourse both by changing the items on the public agenda and by redirecting the resources that are used to obtain them. In short, when viewed in isolation, expansive protection of freedom of speech is neither a good nor a bad. It becomes an unambiguous good only when paired up with a system of limited government and strong property rights.

2. Eliminating "incidental" burdens on speech through property rights.

The structure of property rights influences the patterns of speech and discourse in yet another fashion. It is accepted hornbook law that the First Amendment does not cover regulations of private property that have only an incidental effect upon speech, no matter how large that incidental effect. ${ }^{46}$ Of course, it is understandable that the Supreme Court would adopt a rule of this sort, since it has already decided to scrap any extensive constitutional protection for property rights. It has to police the undeniable friction that takes place at the property/speech frontier. Otherwise, the Court is in danger of indirectly undoing all forms of property regulation in the name of free speech.

This danger is sufficiently great that indirect burdens may be placed on speech so long as the restriction passes nondiscrimination and intent tests. The nondiscrimination test requires that the restriction be imposed upon activities both unrelated and related to speech. The intent test requires that the government not disguise its real purpose to attack speech through the regulation in question.

The net effect of this regime is to countenance a very large reduction in the amount and quality of speech that reaches the public. I have two favorite recent examples of this problem. The first is that of the New York newspapers. Under the above twopronged test, the government can require newspapers (whose editorial content cannot otherwise be regulated) to negotiate with unions under the National Labor Relations Act. As a result, the New York Times has been locked in extensive negotiations with its unions over work crews and job assignments for its modern New Jersey plant, which is capable of printing colored pictures. ${ }^{47}$ Similarly, the New York Daily News has been caught in bitter union

* See Frank I. Michelman, Liberties, Fair Values, and Constitutional Method, 59 U Chi L Rev 91, 112 (1992).

${ }^{17}$ See New York Times Reaches Agreement with Union, Reuters Bus Rep (Dec 12, 1991). 
strikes, which have resulted in violence, disrupted its service, and eventually forced the sale of the Daily News in order to escape labor negotiations. ${ }^{48}$ The second example, which involves both religion and speech, is that of St. Bartholomew's Church in New York. Under the two-pronged test, the government can subject private organizations such as churches to zoning laws which restrict their ability to sell their property. As a result, St. Bartholomew's has been driven toward bankruptcy because it cannot sell or develop its valuable real estate, which has been declared a landmark by the city of New York. ${ }^{49}$ In all of these cases, the courts have refused to single out the press (or religion) for special treatment, determining that the consequences of the regulations, while large, were nonetheless "incidental."

But of course in real life the consequences are more than "incidental." And a stronger system of property protection would have obviated these consequences. All firms would be free to decide the workers to whom they wish to offer jobs, and all landowners would be able to develop their property, subject to the ordinary constraints of nuisance law, without having first to obtain state approval. A greater level of constitutional protection for property rights would prevent the doctrine of incidental effects from stifling constitutional protection of free speech. Indeed, a unified conception of speech and property would leave no place at all for the doctrine of incidental effects under the First Amendment, which is all to the good. That doctrine is but a concession to the reality that there are great losses that must go unredressed-it counts as a point in favor of a unified theory that it can dispense with so unsatisfactory a conception.

A system which protects private property rights, driven by a universal conception of distrust, thus improves speech in two directions. First, it undermines the incentives for unproductive factional speech by eliminating the gains from factional politics. Second, it reduces the cost of the speech that is left, by protecting speech against the incidental burdens of property regulation. And it does both without increasing the dangers of central government control. 1990).

48 See David E. Pitt, News Having Trouble Getting Paper Out, NY Times B4 (Oct 29,

${ }^{19}$ See St. Bartholomew's Church v City of New York, 914 F2d 348 (2d Cir 1990) (upholding New York City's landmark law against Free Exercise Clause and Takings Clause challenges).

so Id at 355 . 
Constitutional law has gone badly astray in creating the massive divide between speech and property. In order to show just how badly off course it has gone, it is useful to examine the doctrinal underpinnings in both speech and takings law. In that light, my views in Takings ${ }^{51}$ will not seem fanciful, idealistic, utopian or anachronistic, for they represent a point-by-point extension to the Takings Clause of much of First Amendment law. The successes of the First Amendment can, and should, point the way to the revitalization of takings law.

\section{Property and Speech: Doctrinal Parallels}

Presently, the great divide between property and speech rests on differing conceptions of distrust in each doctrinal area. The postulate of distrust drives the law of freedom of speech and, with some exceptions, has led the Court to create a coherent and powerful intellectual structure. The opposite presumption of legislative knowledge and probity has led to a continuous judicial horror show with respect to economic liberties and private property, in which judges strain to avoid the literal meaning of constitutional provisions in order to obtain indefensible doctrinal results.

Nonetheless, the possibility of parallel construction of the Free Speech and Takings Clauses should be evident in the parallelism of the questions that arise under both of the clauses: First, what is the scope of the substantive interest to be protected? Second, what government acts violate that interest? Third, what might justify the state in violating that interest? Fourth, what is the remedy for the violation of that interest? Fifth, and perhaps surprisingly for the First Amendment, when does the just compensation principle allow the state to force an exchange?

These five questions are precisely parallel to those that arise in any private law discourse: What is the protected interest? What is the defendant's wrong? What justification can the defendant offer for the prima facie violation of the interest? What is the remedy for the private wrong? When does the libertarian principle yield to forced exchanges?52 Essentially every substantive question in public law can be organized around these five issues. But the range of response may be so different, and parallel interests

\footnotetext{
51 Epstein, Takings (cited in note 2).

52 One example of a forced exchange is the case of private necessity. See Vincent $v$ Lake Erie Transportation Co., 109 Minn 456, 124 NW 221 (1910). The parallels between conditional privilege and the Just Compensation Clause were developed in Dale W. Broeder, Torts and Just Compensation: Some Personal Reflections, 17 Hastings L J 217 (1965).
} 
(speech or property) subject to such divergent legal rules, that it becomes all too easy to forget that the logical structure of the inquiries in both areas is the same.

\section{A. Question One: The Scope of Speech and Property Rights}

The first salient point in comparing speech to property rights is how much broader the coverage is that is given to freedom of speech. Coverage of speech is broader in at least two separate ways. First, it is clear that First Amendment jurisprudence correctly sweeps into its fold all forms of activities whose central mission is to communicate not only ideas and information, but also attitudes, sentiments and feelings. It goes without saying that the First Amendment covers political speech, but it covers artistic and literary expression as well. Similarly, without real tussle, the modern media-for example, fax machines, broadcasts, and electronic mail-are as strongly protected by the First Amendment as the traditional printing press. Finally, even such activities as flag burning $^{53}$ and nude dancing ${ }^{54}$ fall within the purview of the First Amendment. There are some qualifications to the doctrine: Under current theory commercial speech tends to receive lower levels of protection than political speech, although for reasons that should be regarded as insufficient once the connections between speech and property are suitably identified. ${ }^{55}$ And certain other forms of speech, such as fighting words and obscenity, are subject to government regulation. But rarely does the Court pretend that expressive activities are outside the sphere of First Amendment consideration altogether.

Second, constitutional scholars have strained to fit as much expressive activity as possible under the First Amendment. Thomas Emerson's influential theoretical treatment, The System of Freedom of Expression, quite consciously substitutes in the broader term "expression" for the narrower term "speech."56 While the expansion of coverage makes good sense, I believe that Emerson's basic structure is wrong in one critical respect: The linguistic move from speech to expression does not remove the need to ex-

\footnotetext{
${ }^{33}$ See Texas $v$ Johnson, 491 US 397 (1989). 116.

${ }^{51}$ See Barnes $v$ Glen Theatre, 111 S Ct 2456 (1991). See also text accompanying note

${ }^{\circ 5}$ See, for example, Chaplinsky $v$ New Hampshire, 315 US 568 (1942).

${ }^{56}$ Emerson, The System of Freedom of Expression (cited in note 24). Many have picked up the phrase "freedom of expression." See, for example, Stone, et al, Constitutional Law at 1011 (cited in note 7).
} 
plain why certain forms of communication are entitled to absolute immunity from state control. The public justification for restricting speech has to be fought out in terms of the validity of claims made by the state, and not on the strength of a classificatory scheme that looks only to one side of the equation.

The third question about a constitutional right-the state justification for intruding upon the protected interest-cannot be collapsed, without serious loss of intellectual clarity, into the first question-the scope of that right. Yet that is precisely the wrong move that Emerson makes at the outset of his study when he tries to force the complex system of rules regulating communication into the single distinction between "action" and "expression," in which the former is subject to "vastly" more regulation than the latter. ${ }^{57}$ Nevertheless, the broad coverage which Emerson affords speech is surely welcome, for the wide net breathes life into the central proposition of limited government-that all government activities should be evaluated under a presumption of distrust.

The same broad coverage is not given to private property under the Fifth Amendment, but should be. "Private property," like "freedom of speech," is a term of comprehensive import, which surely must be understood to cover more than the rights in land that were well established under the common law of estates. Just as the First Amendment protects (or should protect) the freedom of speech over the airwaves, so too should the Fifth Amendment protect any property rights that individuals acquire in the air rights, ideally through a system of first possession. ${ }^{58}$ Similarly, the

37 Emerson, The System of Freedom of Expression at 8 (cited in note 24). After noting the line-drawing difficulties, Emerson concluded:

But the crucial point is that the focus of inquiry must be directed toward ascertaining what is expression, and therefore to be given the protection of expression, and what is action, and thus subject to regulation as such.

Id at 18. Earlier he had noted that,

in order to achieve its desired goals, a society or the state is entitled to exercise control over action-whether by prohibiting or compelling it-on an entirely different and vastly more extensive basis.

Id at 8 . Emerson, very much a product of the New Deal, did not perceive any serious tension between his authoritarian politics and his libertarian views on speech-an inveterate distinction that I hope to undermine, if not overturn, here.

ss Today the government owns the airwaves, which many think allows the government to control how the spectrum is used or allocated. See National Broadcasting Co. $v$ United States, 319 US 190 (1943); Red Lion Broadcasting Co. v FCC, 395 US 367 (1969). Historically, however, the government did not own the airwaves until after it displaced the spectrum rights originally appropriated through first possession. See Coase, $2 \mathrm{~J} \mathrm{~L} \mathrm{\&} \mathrm{Econ} \mathrm{at} \mathrm{1-7}$ (cited in note 43); Emord, Freedom, Technology, and the First Amendment at 138-65 (cited in note 43). For a criticism of the Court's decision in Red Lion and CBS $v$ Democratic National Committee, 412 US 94 (1973), see Blasi, 1977 Am Bar Found Res J at 611-31 
Takings Clause should protect those forms of property which in some sense are dependent not only upon natural acquisition by individuals, but also upon government recognition, most notably intellectual property-copyrights, patents, trademarks, trade secrets and the like. Likewise, the Takings Clause should protect special forms of property in traditional assets, like time-sharing plans, just as much as it protects traditional forms of property.

Moreover, the definition of property under the Takings Clause is unjustifiably narrower than under analogous private law doctrine. For example, the Takings Clause does not generally protect "good will." But tort law protects goodwill against destruction, and contract law permits private parties to transfer goodwill by legally enforceable agreement. ${ }^{59}$ The unwillingness of the courts to recognize goodwill as an independent item of property, or at least as an element of already recognized business property, represents a true constitutional injustice. ${ }^{60}$

The rationale for this untoward result is conceptual and unsatisfying. It is said that the government only takes ongoing business property that it uses, and not that which it destroys. But recall Blackstone's general injunction that the purpose of compensation when government operates under its power of eminent domain is to ensure that the private holder is not left worse off by the coercive exercise of government power than he was before. ${ }^{61}$ That objective can only be accomplished if the government must compensate for property destroyed. It surely ought not

(cited in note 24). Blasi stresses the power that a free press can have in checking governmental power. Id at 621 . This suggests that easy access to the airwaves (no broadcast rights) will sometimes advance the checking value. Id at 625 . Note too that Emerson calls for extensive social control over licensees, to the ostensible benefit of the public. See Emerson, The System of Freedom of Expression at 660-67 (cited in note 24). But his discussion makes no reference to Coase, and utterly ignores the difference between allocating frequencies, by protecting broadcasts against physical interference, and ordinary content regulation, which should excite serious First Amendment attention.

59 See, for example, Community Redevelopment Agency of Los Angeles $v$ Abrams, 126 Cal Rptr 473, 543 P2d 905 (1975). For criticism of the modern view, see Gideon Kanner, When is "Property" not "Property Itself": A Critical Examination of the Bases of Denial of Compensation for Loss of Goodwill in Eminent Domain, 6 Cal W L Rev 57 (1969).

${ }^{60}$ See, for example, the notorious "Poletown" case, Poletown Neighborhood Council v City of Detroit, 410 Mich 616, 304 NW 455 (1981). There the court's failure to take into account loss of neighborhood goodwill led the court to sustain a takeover of a neighborhood by General Motors that ignored huge elements of losses to the private owners who were dispossessed.

${ }^{61}$ Of the eminent domain power, such as to acquire land for a road, Blackstone asked rhetorically:

In this, and similar cases the legislature alone can, and indeed frequently does, interpose and compel the individual to acquiesce. But how does it interpose and compel? 
make a legal difference if the government destroys a house before it condemns a piece of land instead of condemning the land before destroying the house. The goodwill associated with real property, or even with an ongoing business, should be brought within the scope of the Takings Clause. Unfortunately, courts today, too eager to protect the budgets of municipal governments, allow them to wreak destruction of valuable private assets for which any private malefactor would have to pay. ${ }^{62}$

\section{B. Question Two: The Violation of the Right}

The second part of the problem concerns not the constitutional rights that are protected, but the types of government actions that they are protected from. Although there are countless different schemes of government action, they can best be understood as variations on a few pure types of government action. The most obvious is dispossession-the direct takeover and operation of private activities; others are modifications of liability rules, regulation, and taxation. The following sections compare how the courts have treated each of these four types of government actions when they affect property, and when they affect speech.

\section{Dispossession.}

Within the area of property, there is a sharp disjunction between how the courts treat government dispossession and all other forms of government action. Those cases where the government takes "permanent physical possession" 63 of property are regarded as per se takings, and the government is required to compensate the property-owner for the taking. But with only small qualifications related to when the government compromises the property-

Not by absolutely stripping the subject of his property in an arbitrary manner; but by giving him a full indemnification and equivalent for the injury thereby sustained.

William M. Blackstone, I Commentaries *135 (emphasis added).

${ }_{62}$ I have skirted here the question of whether the government should have to pay for the destruction of goodwill when it does not take property. In my view the answer is yes. If a store serves a neighborhood, and the government tears up the neighborhood so that the store remains, but without customers to frequent it, the store has lost goodwill, here because the government has forcibly interfered with an advantageous business relationship. The state should be required to include this loss of goodwill in working its own calculus of condemnation. To ignore it would allow the government to externalize systematic harms, which in turn would allow the government to condemn too much private land.

${ }^{63}$ Loretto o Teleprompter Manhattan CATV Corp., 458 US 419, 426 (1982). 
owner's "right to exclude," these constitute the only class of per se takings, for which compensation is required.

Within the area of speech, stronger protections apply. The government cannot take permanent physical possession of the New York Times printing presses, even if the government is prepared to pay compensation. The protection afforded speech against dispossession thus goes beyond that afforded property, but for reasons that are consistent with the basic logic of the Takings Clause. The reason why some takings of private property are allowed, with just compensation, is that the forcible rearrangement of property rights is understood to provide some net social benefit. But where is the net benefit when speech is suppressed? The interest in speech is typically relational-communication is of benefit to the audience as well as to the speaker-and no compensation formula easily takes that interest into account. If the government needs a printing press, it knows where to buy it; so too with raw land. On the other hand, there is the real risk that the government will condemn newspapers simply to suppress criticism. In short, prohibiting this limited class of prospective condemnations prevents hardly any socially beneficial transactions, while permitting them raises the persistent specter of government abuse. Thus the government takeover is flatly forbidden under the First Amendment.

\section{Modification of liability rules.}

The Court has held on a number of occasions, even before $1937{ }^{65}$ that no person has any vested right in any common law rule of liability. But there has been a long line of Supreme Court cases in which the very forms of liability rules that provoke only yawns under the Takings Clause have received close attention under the Free Speech Clause. For instance, under the First Amendment, the rules of tort liability are regarded as essential subjects for mischief and abuse, and hence are given close constitutional scrutiny. The results can lead to the fortification of some common law rules of

\footnotetext{
64 Loretto relied heavily on Kaiser Aetna v United States, 444 US 164, 179-80 (1979), in which the Supreme Court found a taking where the government had demanded public access to a private marina. The case was not one of dispossession, for the state did not seek to exclude the private owner from the use of the marina. But the state did compromise the right to exclude, which the Court found a fundamental stick in the bundle of property rights. To a property lawyer, the case is too easy to require extended comment. There is a taking whenever A requires B, a sole owner, to become a joint tenant with A against B's will. Otherwise A could force the joint tenancy, then partition, and through two steps take half of what $B$ owns. Do it enough times and we have a new cottage industry of dubious worth.

${ }^{65}$ See, for example, New York Central R.R. Co. $v$ White, 243 US 188, 198-200 (1917).
} 
liability, but to the repudiation of others. Thus, in New York Times $v$ Sullivan, ${ }^{66}$ the Court refused to show any deference to the settled common law of defamation; instead, all of its substantive dimensions were subject to constitutional review, and in some instances revision. Thus the state cannot expand the definition of the identification requirement ("of and concerning the plaintiff") beyond the scope that it had at common law. More dramatically, the courts have found that certain critical features of common law protections for defendants have been inadequate. The strict scrutiny of liability rules, moreover, is not only directed at issues that are tangential to the overall soundness of the system, but is directed to issues that go to its heart: awarding general damages; ${ }^{67}$ putting the burden of proof on the defendant to show truth; ${ }^{68}$ and, most importantly, extending the privilege of "fair comment" to cover not only statements of opinion, but also false statements of fact, unless the media defendant knows them to be false or acts in reckless disregard of their truth or falsity. ${ }^{69}$

All these innovations should not be viewed in the same light. In some instances the Supreme Court reads the First Amendment in a sound fashion-to maintain requirements of proof that are demanded by a consistent theory of individual freedom. Placing the burden of proof on a plaintiff to prove that certain facts are false is one such innovation. But, in other instances, as with giving extensive protection to false statements of fact, the Supreme Court goes far beyond that modest office, and quickly gets itself into trouble. The major criticism of the modern law of defamation is that it affords no effective redress for public officials and public figures who have been victimized by false statements. Media defendants are allowed to shield themselves from the harmful consequences of their acts, merely by admitting that they were negligent. ${ }^{70}$ Finally, in some cases, like the doctrine of presumed damages, the balance of equities is sufficiently close that one wonders why the court finds it

66376 US 254 (1964).

${ }^{67}$ See, for example, Gertz v Robert Welch, Inc., 418 US 323, 348-50 (1974) (no recovery for presumed or punitive damages).

\& Philadelphia Newspapers Inc. v Hepps, 475 US 767, 776-78 (1986) (private-figure plaintiff in defamation action bears burden of showing that alleged defamatory speech is false).

19 New York Times, 376 US at 279-80. For my defense of the common law baseline in this connection, see Epstein, 53 U Chi L Rev 782 (cited in note 9).

70 See, for example, Randall P. Bezanson, Gilbert Cranberg, and John Soloski, Libel Law and the Press: Myth and Reality 214-18 (Free Press, 1987) (criticizing focus of defamation law on defendant's mental state and advocating separate procedures that allow adjudication of question of truth even where plaintiff cannot establish actual malice). 
imperative to upset a balance of interests that seems to have worked well over time, absent an evidence of systematic abuse or untoward social consequences.

There are many errors of detail in First Amendment defamation law, virtually all of which stem from its deviation from superior common law principles. But the mistakes in application do not deny the bedrock proposition of New York Times: there should be constitutional scrutiny of the law of libel. That scrutiny of liability rules should carry over to the Fifth Amendment. As a matter of general theory, there are not two watertight compartments: one for property rights, protected by the Constitution; the other for liability rules, subject to legislative discretion and control.

To test the proposition by the extreme case, it seems clear that the total repeal of the law of trespass would constitute a complete revolution in the basic civil order. If individuals are not allowed to exclude deliberate trespassers from their ranks, then we have retreated from a system of ordered government to a system of state-sanctioned anarchy. The right to exclude under the rubric of private property has been protected in some cases. ${ }^{71}$ But in many others, such as when factory owners seek to exclude union organizers from their land, the Supreme Court has looked upon the suspension of the common law rules of trespass not with doubt and suspicion, but with relief and welcome. ${ }^{72}$ Similarly, in the entire area of environmental regulations, it is clear that any appeal to ideas of trespass, or nuisance, or the right to exclude carries little weight in the present constitutional order..$^{73}$

To hold, as I argue, that legislative modifications of liability rules fall under the Takings Clause would not preclude the state from justifying its modification by appealing to the overall welfare of the community. In fact, it would facilitate a rigorous demonstration of that defense in those cases where it can be mounted. But

71 See Kaiser Aetna, 444 US at 179-80.

${ }^{72}$ See Republic Aviation Corp. v NLRB, 324 US 793, $802-05$ (1945); Beth Israel Hospital v NLRB, 437 US 483, 491-93 (1978). There are, of course, complications in this area, given that outside organizers may well be regarded as trespassers, even though present employees whom the employer wants to exclude are not. See NLRB v Babcock \& Wilcox Co., 351 US 105, 112 (1956); Lechmere, Inc. v NLRB, 112 S Ct 841 (1992). But now the judicial vice is to mangle the common law of trespass, instead of just disregarding it. The traditional view was clear that entry was limited to the time of its allowance, and to the purposes for which it was granted. See The Six Carpenters' Case, 77 Eng Rep 695, 8 Co Rep 146 (1610).

${ }^{73}$ See, for example, Miller $v$ Schoene, 276 US 272, 280 (1928) (state act providing for the destruction of red cedar trees located within two miles of apple trees found to be constitutional, even though no compensation was given for value of standing trees or decrease in value of realty). 
the converse-exclusion from constitutional scrutiny of most modifications of liability rules-can lead to the radical destabilization of the system of property rights, with (as I shall show later) long-term adverse consequences for the political and social system.

\section{Regulation.}

Liability rules are only one way in which the government, particularly the activist government, has altered the distribution of property holdings among the citizenry. The government has achieved the same result by imposing various schemes of regulation, such as those which were sanctioned in the early rent control and zoning cases. And the property-owner must overcome a very heavy set of burdens to obtain compensation from the state. Indeed, the Supreme Court has positively gloried in its inability to articulate clear rules to govern this area: the Court has pretended to decide each alleged regulatory taking on an ad hoc basis. ${ }^{74}$ In fact, however, the Court has adopted a rule that is predictable, but incorrect: a virtually conclusive presumption against requiring compensation for any regulation.

In contrast, regulation is an abridgment of speech under the First Amendment in a way that it is most definitely not a taking (even a partial taking) of property under the Fifth Amendment. Where regulations of speech are imposed, the Supreme Court has an elaborate classification system designed to cull out unacceptable forms of regulation. There are divisions into high and low value speech, and into content-based and content-neutral regulations, each with its own pattern of justification..$^{75}$ But there is not the slightest suggestion anywhere in the entire body of First Amendment law that "mere" regulation of speech is outside the scope of the First Amendment. The clear perception is that the unrestrained state can stifle speech and dissent through regulation just as easily as through a direct ban. Bond or permit requirements for speakers are always closely scrutinized to see if they conceal an illegitimate effort to restrict the scope of speech generally. ${ }^{76}$ Special scrutiny is imposed where there is the slightest hint that the restrictions are linked to the speaker's viewpoint, however distaste-

\footnotetext{
74 See, for example, Penn Central Transportation Co. $v$ New York City, 438 US 104, 124 (1978).

is See text accompanying note 29.

${ }_{76}$ See, for example, Cox $v$ New Hampshire, 312 US 569 (1941) (conviction upheld in parade statute prosecution only because state court had held that local licensing officials could only consider time, place, and manner restrictions).
} 
ful that viewpoint may be to the public at large. ${ }^{77}$ The fear of abuse of this regulatory power is the most salient explanation for this aspect of First Amendment law.

Analytically, there is no ground for the distinction between regulatory takings and infringements of free speech. The state has taken the fee simple, even if it returns some portion of the land by way of compensation. Likewise, it has taken the fee simple if it confiscates it, but then returns it subject to new restrictions on use and disposition. Restrictive covenants are property interests when created by consent, and they remain so imposed by the state. What one side-the covenantee-obtains, the other side-the covenantor-loses. To treat these regulations as "mere" restrictions that fall outside the scope of the Takings Clause is to immunize vast areas of government behavior from judicial scrutiny in a manner that would be incomprehensible under the First Amendment.

\section{Taxation.}

The last mode of government attack on private behavior is through a system of taxation. While the formal possibility of mounting a successful takings challenge against taxation is not explicitly denied by the Court, it is well-nigh impossible to find any challenge that has succeeded, even before $1937 .{ }^{78}$ As for regulations, the courts have adopted a virtually conclusive presumption against requiring compensation for any tax.

Long ago, Justice Marshall's famous aphorism warned that the power to tax was the power to destroy. ${ }^{79}$ As government taxes continued to rise even before the end of the Lochner period, Justice Holmes, who had so much to do with the expansion of the government power to tax, was led to say, in essence, "so what?"вo Judges continue to solemnly maintain that egregious taxes will fall under the Takings Clause, but if the Supreme Court has invalidated a tax on takings grounds in the past seventy-five years, I am not aware

77 See, for example, Thomas $v$ Collins, 323 US 516, 540 (1944) (invalidating Texas statute that required union organizers to obtain permit).

78 For a typical statement, see Magnano Co. $v$ Hamilton, 292 US 40, 44 (1934) (Th[e Takings] Clause is applicable to a taxing statute such as the one here assailed only if the act be so arbitrary as to compel the conclusion that it does not involve an exertion of the taxing power, but constitutes, in substance and effect, the direct exertion of a different and forbidden power, as, for example, the confiscation of property.").

79 See McCulloch v Maryland, 17 US 316, 431 (1819).

so See Alaska Fish Co. $v$ Smith, 255 US 44, 48 (1921) ("Even if the tax should destroy a business it would not be made invalid or require compensation upon that ground alone. Those who enter upon a business take that risk."). 
of it. The basic principle is evidently that the mere benefit of living in a civilized society is sufficient justification for the imposition of any tax, however indefensible its incidence or form. ${ }^{81}$ The dangers that unsound systems of taxation can work to the operation of the economic system are not factored into the constitutional equation. But to deny that taxes are takings-when they involve the threat of seizure for those who do not voluntarily hand over property-is to use a definitional ploy to answer a question that calls for a policy response: Which forms of taxation are permissible in a democratic society, which are out of bounds, and why?

The attitude toward taxation under the First Amendment is quite different. It is recognized that taxation is yet another form of government control, which, if placed in the wrong hands or directed to the wrong means, can distort the political system. It is clear that the protection of various forms of speech against taxation does not absolutely prohibit taxation: newspapers can be taxed on their business profits like other organizations. But it has led to scrutiny of the permissible justifications for taxation, and of the permissible forms of taxation. ${ }^{\mathbf{2}}$

In sum, within the law of takings, the broad class of partial takings-changes in liability rules, regulations, taxation-are all thought to trigger at most a cursory review, if they are regarded as takings at all. ${ }^{83}$ The evasiveness of the mode of analysis is always calculated to impress upon us the need for judicial deference and legislative discretion, and thereby the justification to expand the use of government force. With the regulation of property, the pattern of judicial deference stems from the want of any deep conviction that limitations on government power are beneficial, and from the consequent unwillingness to formulate any principles that have bite. $^{84}$

${ }^{81}$ See Carmichael v Southern Coal Co., 301 US 495, 522 (1937) ("The only benefit to which the taxpayer is constitutionally entitled is that derived from his enjoyment of the privileges of living in an organized society, established and safeguarded by the devotion of taxes to public purposes.").

${ }^{82}$ See Section III.E.2.

${ }^{83}$ See, for example, Penn Central, in which Justice Brennan found that New York City's landmark preservation law was not a "taking" of the plaintiff's property. 438 US at 136-38. But Justice Brennan left open the possibility that, if the designation system were a taking, then government would have adequately compensated the plaintiff by awarding it transferable development rights ("TDRs"), even though the TDRs were worth only a tiny fraction of the value of the air rights of which the government had deprived the plaintiff. Id at 137. Yet under the later holding in Kaiser Aetna, 444 US at 180, the case would have been a taking if the government had sought to build on the plaintiff's property itself, instead of taking what is in essence a restrictive covenant on height.

8s See, for example, Justice Brennan's statement in Penn Central: 
There is no similar relaxed or deferential attitude within the law of speech. Commentators who care about the principle always warn that "[a] system of freedom of expression can be successful only when it rests upon the strongest possible commitment to the positive right and the narrowest possible basis for exceptions. And any such exceptions must be clear-cut, precise, and readily controlled." 85 All attacks on private speech are regarded as potentially deadly threats to the operation of the marketplace of ideas, or to full and active participation in the political process. The Court never takes the view so common in property cases that the "wisdom" of the legislation bears no relationship to its constitutionality.

C. Question Three: Justifications for Government Restrictions on Speech and Property

It is clear to limited government libertarians that liberty should not be regarded as equivalent to anarchy, either as a matter of first principle or as a matter of constitutional interpretation. The idea of anarchy is that any person is allowed to speak or do anything that he chooses, and that the sole restraint upon that conduct is private force. Within a legal system, however, the concept of liberty always means what Cardozo once termed "ordered liberty"86-restraints on the freedom of action that take into account the correlative duties that individual actors owe to others. That these duties exist is perfectly apparent in the world of individual actions: the right to own property and to use it as one pleases is not an authorization to kill the first person with whom one has a minor disagreement.

I believe that the system of libertarian justifications is traceable to a powerful set of utilitarian roots. ${ }^{87}$ Restrictions on the individual's capacity to act are based on the view that all persons are better off by sacrificing their natural liberty of action than by exer-

While this Court has recognized that the "Fifth Amendment's guarantee ... [is] designed to bar Government from forcing some people alone to bear public burdens which, in all fairness and justice, should be borne by the public as a whole," Armstrong $v$ United States, 364 U.S. 40, 49 (1960), this Court, quite simply, has been unable to develop any "set formula" for determining when "justice and fairness" require that economic injuries caused by public action be compensated by the government, rather than remain disproportionately concentrated on a few persons.

438 US at 123-24. It is easy to fail if you do not try.

${ }^{85}$ Emerson, The System of Freedom of Expression at 10 (cited in note 24).

${ }^{86}$ Palko v Connecticut, 302 US 319, 325 (1937).

${ }^{87}$ I have developed this idea in Epstein, 12 Harv J L \& Pub Pol 713 (cited in note 34). 
cising it in a world where others use their natural powers against them. The prohibition against the threat of force thus arises from the mutual renunciation of the private use of force, obtained not through voluntary agreement, but by government edict, needed to overcome the holdout and bargaining problems that otherwise would exist. However, for these purposes it is not important to detail the exact derivation of these utilitarian claims, for the restrictions on the use of property and freedom of action are accepted by virtually every one, including those who conceive of a far broader set of public justifications for the restriction of property and/or speech.

What is equally clear under libertarian theory is that there is no artificial divide between speech and property when the question is whether there is any justification for limiting individual actions. Freedom of speech implies the same limitations associated with freedom of action, or with freedom of contract. The same concerns with force and fraud that arise under the general libertarian theory surface with great force in efforts to discover the appropriate limits of both speech and property rights. For instance, the threat of force will often involve the use of speech, and if not speech, then surely those forms of expression (for example, gestures or signs) that fall comfortably within the narrowest definitions of expression championed under modern theory. The mere fact that the threat and the use of force are equated under the general theory shows that both speech and conduct are subject to the same sort of scrutiny, and for much the same reason: to improve the overall operation of the social system.

1. Justifications for restricting free speech.

a) Preventing private force. Many First Amendment cases deal with the government's power to punish conduct that involves the threat or use of force. The entire line of sedition cases, from the outset of the First World War until the 1950s, were largely devoted to a single question: When, and how, could the government impose restrictions upon speech that posed the risk of physical danger or disruption of public services? ${ }^{88}$ Holmes put the issue squarely in Schenck when, in conjunction with his reference to shouting "Fire!" in a crowded theater, he noted that "[the most stringent protection of free speech] does not protect a man from an

\footnotetext{
${ }^{88}$ For a collection of the relevant cases and materials, see Stone, et al, Constitutional Lau at 1025-1100 (cited in note 7).
} 
injunction against uttering words that may have all the effect of force." threatened riot or mayhem..$^{30}$

During the formative period of modern First Amendment jurisprudence, the police power of the state was confined to police work. No matter how much we have come to disapprove of Schenck, and to admire Abrams v United States, ${ }^{91}$ the exceptions to the basic protection of speech were always associated with the preservation of the public order against the risk of treason or violence. The significant debates over the scope and limitation of the "clear and present danger" test were all about the narrow class of ends that government could permissibly suppress. If the speech in question threatened conduct that was not a common law offense against person, property, or national security, then its suppression was inconsistent with freedom of speech. There was no discussion about the irrelevance of the common law, or the search for novel baselines congenial to the New Deal era. There was an extensive debate over how far back to roll the carpet in order to protect against the overthrow of the government, an issue on which strong disagreement is possible. ${ }^{92}$

The current constitutional equilibrium on subversive speech, reached in Brandenburg $v$ Ohio, ${ }^{93}$ is consistent with the general libertarian approach:

[T] he constitutional guarantees of free speech and free press do not permit a State to forbid or proscribe advocacy of the use of force or of law violation except where such advocacy is

${ }^{89}$ Schenck, 249 US 47, 52. See also note 28 (discussing Kalven's views).

${ }^{\circ}$ See, for example, Chaplinsky v New Hampshire, 315 US 568 (1942), in which the Court noted the "fighting words" exception to the First Amendment, and narrowly construed it to cover only those words "which by their very utterance inflict injury or tend to incite an immediate breach of the peace." Id at 572. See also Feiner $v$ New York, 340 US 315 (1951), in which the Court similarly limited "fighting words" to those which posed an "immediate threat to public safety, peace or order," and sustained a conviction on those grounds alone. Id at 320, citing Cantwell v Connecticut, 310 US 296, 308 (1940).

91250 US 616 (1919) (knowledge of probable consequences of distributing circulars sufficient to sustain conviction under Espionage Act of 1918).

${ }^{92}$ See Gitlow v New York, 268 US 652 (1925) (requires "language of direct incitement" "used with intent and purpose"); Whitney $v$ California, 274 US 357 (1927) (stressing deference to the legislature, upheld conviction for membership in an organization advocating criminal syndicalism); Dennis v United States, 341 US 494 (1951) ("whether the gravity of the 'evil,' discounted by its improbability, justifies such invasion of free speech as is necessary to avoid the danger"); Yates $v$ United States, 354 US 298 (1957) ("those to whom the advocacy is addressed must be urged to do something, now or in the future, rather than merely to believe in something").

${ }^{93} 395$ US 444 (1969). 
directed to inciting or producing imminent lawless action and is likely to incite or produce such action. As we said in Noto $v$. United States, 367 U.S. 290, 297-98 (1961), "the mere abstract teaching ... of the moral propriety or even moral necessity for a resort to force and violence, is not the same as preparing a group for violent action and steeling it to such action." 94

By the same token, it goes without saying that offensiveness does not limit the scope of First Amendment protection. The flag-burning case is the most salient illustration of political speech, designed to offend, but which nonetheless cannot be regulated because it does not pose an imminent threat of violence. ${ }^{95}$

The reasons for judicial protection are instructive on the theme of distrust. It is not that the harms caused by flag-burning and similar activities are not real, for they are, or that they are not substantial, for that they may be as well. ${ }^{96}$ Instead, it is that the risks of collective reprisal are rightly regarded as so great that the government is required to stay its hand. The class of external harms that justify the police power are sharply, even artificially, limited in order to limit the scope of government action. The parallel here is to the common law conception of damnum absque injuria ("harm without legal injury"), which is imposed not because other persons have suffered no harm, but because the freedom of action and the social gains which that freedom brings are only possible when certain forms of harm (for example, offense, competitive loss) are not recognized by the legal system..$^{97}$

The question of external harms does not arise, however, only in subversive advocacy cases, but in other less dramatic contexts as well. Public speech can often be noisy and offensive, and it is clear that the Court tolerates "time, place, and manner" restrictions on speech. ${ }^{98}$ Two features about these regulations should be quickly noted. First, they are directed against conduct that the common

94 Id at 447-48. Note that one could quarrel with this decision on the ground that it is too protective of speech. There may be some harms so serious in their implications that the imminence requirement should be relaxed. But for these purposes, the rule falls squarely within the libertarian tradition, and tallies closely with Chaplinsky.

${ }^{95}$ See Texas $v$ Johnson, 491 US 397 (1989).

98 "If there is a bedrock principle underlying the First Amendment, it is that the government may not prohibit the expression of an idea simply because society finds the idea itself offensive or disagreeable." Johnson, 491 US at 414.

07 This point was first developed in Oliver Wendell Holmes, Jr., Privilege, Malice, and Intent, 8 Harv L Rev 1, 2-10 (1894).

${ }_{88}$ See Stone, et al, Constitutional Law at 1257-1337 (cited in note 7). 
law ordinarily treats as nuisance, such as the use of loudspeakers or sound trucks in public places. ${ }^{99}$ Second, the problem of selective enforcement looms large even when the regulations are contentneutral, and is taken into account when the courts review the enforcement of these "time, place, and manner" restrictions. These restrictions on speech thus require principled justification as well.

b) Preventing private fraud. Other speech restrictions are justified on the grounds that they prevent private fraud or misrepresentation. The libertarian rationale for the tort of defamation is that it constitutes the wrong of misrepresentation, directed not to the victim of the wrong, but to some third party. The New York Times line of cases shows how even misrepresentation cases are greeted with hostility, in large measure because of the suspicion of the abuse of government power. ${ }^{100}$ And the same attitude of caution is shown toward state efforts to regulate the conduct, for example, of union organizers, even under circumstances where there is persuasive evidence of private fraud. ${ }^{101}$

Even the commercial speech cases have shown some signs of falling into the same pattern. In principle, these cases show the impossibility of maintaining the strong line between action and expression that drives Emerson's analysis of the First Amendment. A price system is best understood as a system of communication that impounds relevant information. Thus a system of price controls is best understood as an interference with the way in which the price system transfers that information. ${ }^{102}$ Direct attacks on price controls based on takings. or allied grounds have had only rare success. ${ }^{103}$ But while the price mechanism has not been brought under the First Amendment, ordinary forms of advertisement have been, and here the libertarian potential of the First Amendment sometimes surfaces.

${ }^{90}$ See, for example, Kovacs v Cooper, 336 US 77 (1949).

100 For an overview of the New York Times line of cases, see Stone, et al, Constitutional Law at 1145-71 (cited in note 7).

${ }^{101}$ See Thomas v Collins, 323 US 516 (1945) (statute requiring labor organizers to obtain a permit soliciting workers to join unions invalid under the First Amendment).

${ }^{102}$ For an elaboration of the point, see Daniel Shapiro, Free Speech, Free Exchange, and Raulsian Liberalism, 17 Social Theory and Practice 47, 50-57 (1991).

${ }_{103}$ For one recent victory, see Calfarm Insurance Co. v Deukmejian, 258 Cal Rptr 161, 771 P2d 1247, 1252-56 (1989) (granting relief against automatic $20 \%$ rollback in insurance proposal). For one recent failure, see State Farm v State of New Jersey, 124 NJ 31, 590 A2d 191 (1991) (rejecting challenge to New Jersey's insurance reform legislation). 
Take a case in point. In Virginia State Board of Pharmacy $v$ Virginia Citizens Consumer Council, ${ }^{104}$ the Court struck down state restrictions that barred pharmacies from advertising the price at which they sold their goods. The fanciful justifications that were offered for such regulation all had an economic cast: that advertisement would lead to a loss of the professional image among pharmacists; that able firms would be driven out of business because of their inability to compete on price, leaving a clear field to the predators to drive up the price thereafter. ${ }^{105} \mathrm{Had}$ this been a challenge based on the Due Process Clause, the Court indicated that these rationales, however specious, could have justified the statute. ${ }^{106}$ But within the framework of the First Amendment, the Court immediately reverted to the libertarian analysis, and noted that the seller of a high-quality product could advertise quality in opposition to price. ${ }^{107}$ It has been said that this decision resurrected substantive due process, ${ }^{108}$ and so it did, but that should be regarded as one of its strongest features, not as one of its drawbacks.

\section{Justifications for restrictions on property rights.}

In most cases involving property or economic liberties, however, the police power, now used as a term of art, has grown so that it bears no relationship to the control of either force or fraud. Few cases of land use regulation, for example, are concerned with the control and use of force in any form. The nearest kin to trespassory force is nuisance; yet the nuisance control rationale for the police power in land use cases has been repeatedly rejected as an authoritative basis for deciding these cases. ${ }^{109}$ Often the nuisance control rationale is rejected on conceptual grounds: that it is impossible to tell who has caused a nuisance and who has been a victim. ${ }^{110}$ This is ironic, because the nuisance control rationale is an

104425 US 748 (1976).

105 Id at $764-70$.

106 Id at 769.

107 Id at 769-70. The Court did, of course, permit regulation against advertisements that were "false or misleading in any way." Id at 771.

${ }^{108}$ See Thomas H. Jackson and John Calvin Jeffries, Jr., Commercial Speech: Economic Due Process and the First Amendment, 65 Va L Rev 1, 29-33 (1979).

109 The process started in the 1920s with Euclid v Ambler Realty Co., 272 US 365, 38788 (1926), and Miller $v$ Schoene, 276 US 272, 280 (1928), and continues today.

11 The view has also been defended in Michelman, 80 Harv L Rev at 1196-1201 (cited in note 6); Joseph L. Sax, Takings and the Police Power, 74 Yale L J 36, 48-50 (1964); Joseph L. Sax, Takings, Private Property and Public Rights, 81 Yale L J 149, 161-69 (1971). I have criticized the view in Takings at 115-21 (cited in note 2). 
important distinguishing principle for content-neutral cases under the First Amendment. On the one hand, content-neutral regulation designed to limit the use of sound trucks is routinely upheld. ${ }^{111} \mathrm{On}$ the other hand, legislative characterizations of certain other conduct as "nuisances"- such as the distribution of handbills-are accorded virtually no weight at all. ${ }^{112}$

The difference in approach yields powerful differences in consequences. Once all specific content has drained out of the police power language, any legitimate public function of conceivable merit justifies government restriction on land use. The narrow account of external harms accepted under the First Amendment no longer limits what the state may do under the Fifth Amendment. Aesthetics, popular sentiments, and environmental objectives all become appropriate pegs on which to hang legal justifications for land use restrictions. ${ }^{113}$ No explanation is given as to why the narrow account of external harms under the First Amendment is so inappropriate here. As the ends have widened, so too the means to achieve those ends have been broadly construed, and all the burdens of proof are set in favor of the state, so that any challenge of land use restrictions is always an uphill battle.

Notwithstanding the many differences in the reach of the police power in speech and property cases, there does exist some convergence between them, namely under the shadowy protection of the public "morals" facet of the police power. Here the great problems arise in mixed cases, such as those involving billboards ${ }^{114}$ or "adult" movie theaters, ${ }^{115}$ where the level of regulation tolerated by the courts is normally higher than that associated with speech alone. In part, the rationale for these decisions is that the regulations deal not only with speech, but also with land use, where the standards of review are clearly much lower. The outcomes are in part defensible, especially if one could demonstrate that certain private activities increase the risk of neighborhood violence and disorganization. In some cases, such as the recent nude dancing decision, ${ }^{116}$ problems of land use and free speech converge. The prin-

\footnotetext{
11 See note 99 and accompanying text.

112 See, for example, Lovell, 303 US 444,451 (voiding city ordinance which put prior restraint upon distribution of handbills and similar literature as "nuisances").

${ }^{113}$ See, for example, Berman v Parker, 348 US 26, 32-33 (1954) (holding that-protection of "spiritual" and "aesthetic" values was a legitimate exercise of municipality's police power).

11 See Metromedia, Inc. v San Diego, 453 US 490 (1981).

116 See Young $v$ American Mini Theatres, 427 US 50 (1976).

116 Barnes v Glen Theatre, 111 S Ct 2456 (1991).
} 
ciples of individual freedom collide with the "morals" facet of the police power, which sometimes operates as a supplement to, and at other times as an extension of, the state's power to prohibit various forms of violence and fraud.

These difficult cases lie at the edge of the law under any comprehensive theory, and for my purposes, at least, the location of the proper line is not the dominant concern. The so-called "morals" cases represent the easiest extension of the police power in a land use setting, and the most difficult extension of the police power in a First Amendment setting. It is the radically different responses to the easy cases that marks the difference under the two amendments. A more unified approach to the questions of speech and property would aid in the design of a more satisfactory legal response.

\section{Question Four: The Choice of Remedies}

The differences in judicial treatment of speech and property are also revealed in the selection of remedies against individual actors that have committed some wrong. In principle, there is a wide range of remedies available for any wrong. Some of these remedies are imposed through direct government action, as when the criminal law provides for imprisonment and fines. In addition, there is a full range of administrative and regulatory remedies designed to eliminate the harm before it begins. Injunctions can be issued against threatened harms, and most importantly a system of permits and licenses can be imposed in order to prevent these harms in the first place. Similarly, on the private side, individual plaintiffs may seek orders for damages, orders for restitution, or injunctions. In those cases where there is only a single isolated harm, the choice of remedy is relatively constrained: damages matter, injunctions do not. But with institutional defendants capable of repeat offenses, systems of social control and systems of prior restraints are feasible, and, in some circumstances-for example, driver's licenses-desirable as well.

\section{Prior restraints on speech.}

As with other parts of the overall system, the choice of remedies is driven in large measure by the fear of government abuse, relative to private abuse. In the First Amendment area, there is a virtual per se rule against any prior restraint of publication, no matter how harmful or defamatory the material might be. Historically, a fear of prior restraint was the first great motivating force of 
the free speech tradition, dating back to Milton and Blackstone. ${ }^{117}$ In its modern form, once a restriction is identified as a prior restraint, any individual citizen is free to act in defiance of that restriction without exhausting any available administrative remedies. ${ }^{118}$ There is no possibility that the state can postpone publication of controversial speech by making grudging administrative concessions after intolerable procedural delays.

There have been a wide variety of concerns with the licensing power, all of which work back to the common theme of distrust. It is said that licensing concentrates too much power in the hands of a small group of individuals, not only when it provides for administrative remedies, but even when it provides for judicial review of individual cases. ${ }^{119}$ It is said that the want of clear standards only increases the risk of the improper use of discretion by political actors. ${ }^{120}$ It is said that prior restraint keeps relevant information off the market; thus it denies the audience the right to read and comment on that information itself, and it denies the author the right to publish the material so long as he or she is prepared to pay the price. ${ }^{121}$ It is said that the procedural protections from administrative hearings are likely to be lower than those of judicial proceedings, especially in a criminal context. ${ }^{122}$ It is all true.

The upshot is that any form of prior restraint is struck down, even when there is an arguable ground for issuing an injunction under ordinary common law principles, as was the circumstance in the Pentagon Papers case. ${ }^{123}$ Prior restraints of all forms and de-

117 John Milton, Areopagitica: A Speech for the Liberty of Unlicensed Printing, to the Parliament of England, in George H. Sabine, ed, Areopagitica and Of Education (Harlan Davidson, 1951); William M. Blackstone, 4 Commentaries *151 ("The liberty of the press is indeed essential to the nature of a free state: but this consists in laying no previous restraints upon publications, and not in freedom from censure for criminal matter when published.") (emphasis in original).

11 See Lovell, 303 US at 452-53 ("As the ordinance is void on its face, it was not necessary for appellant to seek a permit under it. She was entitled to contest its validity in answer to the charge against her.").

119 Near $v$ Minnesota, 283 US 697, 715 (1931) (Minnesota statute authorizing state to seek injunctions against routine publishers of malicious or defamatory information on the grounds of nuisance found unconstitutional).

120 City of Lakewood v Plain Dealer Publishing Co., 486 US 750, $769-70$ (1988) (ordinance granting mayor absolute discretion in granting of applications for annual permits to place newsracks on public property found unconstitutional).

${ }^{121}$ See Thomas I. Emerson, The Doctrine of Prior Restraint, 20 L \& Contemp Probs $648,656-60$ (1955).

122 Id at 657. See also Vincent Blasi, Toward a Theory of Prior Restraint: The Central Linkage, 66 Minn L Rev 11, 43-47 (1981).

${ }^{123}$ New York Times Co. $v$ United States, 403 US 713 (1971) (lifting temporary injunction against publication of information leaked to papers by Daniel Ellsworth). Among the 
scriptions are routinely disallowed, save under the most extraordinary circumstances-such as where I can show you how to make a nuclear bomb cheaply. Other criminal and civil sanctions are required.

\section{Prior restraints on property use.}

The situation is radically different under the Takings Clause, where today it is virtually impossible for any private party to maintain a facial challenge against any form of land use regulation. Instead, the dominant rule requires that all administrative remedies first be exhausted, and that constitutional challenges be brought on an "as applied" basis. ${ }^{124}$ The risk of government misbehavior due to local or national politics is as large here as it is with speech restrictions: there are dangers of excessive local power and bias; there are costs to outsiders (the potential buyers of the developed property) which are ignored in setting the social calculus; there is far less protection than in any judicial proceeding. There is no reason to believe that public officials who improperly thwart the distribution of leaflets will become impartial solons on economic matters. No one has that kind of a split brain, with virtue in the property hemisphere, and vice in the speech hemisphere.

Yet there is scant recognition of the evils that are endemic in this area and the social dislocations that can follow. The Supreme Court is quite content to require individual property-holders to file endless requests for variances with hostile zoning boards before considering a case at all. ${ }^{125}$ None of the concerns with permits that dominate the First Amendment area carry over to the Takings Clause. Instead the Supreme Court has written: "[A]fter all, the very existence of a permit system implies that permission may be

reasons offered for the decision was that Congress had only authorized criminal sanctions against the individuals who improperly obtained or retained forbidden information, so that the decision dealt as much with separation of powers as with freedom of speech. See id at 740-48 (Marshall concurring). But at common law, a private party could normally obtain relief against a third person who acquired property with knowledge that it was not owned by the immediate seller. In principle, the analogous rule could apply to sales of information. The injunction could then be applied against persons who received stolen information in bad faith, that is, with knowledge that it had been obtained illegally.

${ }^{124}$ Hodel $v$ Virginia Surface Mining \& Reclamation Ass'n, Inc., 452 US 264, 297 \& $n$ 40 (1981).

${ }^{225}$ Williamson Planning Comm'n v Hamilton Bank, 473 US 172, 186-88 (1985) (plaintiff seeking zoning approval had to exhaust all available administrative remedies, including petitioning the administrative agency for variances). 
granted, leaving the landowner free to use the property as desired." 126 Oh?

This steadfast refusal to provide early and prompt remedies in takings cases is intimately tied to the basic propositions of takings law. The Supreme Court has noted that its own fuzzy standards of what constitutes a taking make it impossible to decide whether the government has misbehaved, and to decide what compensation, if any, to require before a matter has been brought to a close. ${ }^{127}$ The upshot is that local governments are utterly free to ignore the interests of those whom they regulate, so long as they are willing to throw elaborate hurdles in the paths of those who would challenge their regulations. The risk of local bias and the social losses that follow from the partial or permanent development of property may well be great, but there is no way to force the issue to adjudication.

Instead of the present rules that tolerate abusive behavior and foster costly delays, the system should be redone from the ground up. The permit system should be scrapped. Neighbors and local governments should be able to sue to enjoin the completion or operation of local land uses only by showing that there is some imminent (I would settle for serious) danger of external harms. Where the future harm is uncertain, and the project goes forward, then the landowner might be required to post bond to make good the losses that its conduct might impose on strangers.

The stakes on prior restraint may not be as high for property as they are for speech, although it is hard to be dogmatic on the point without knowledge of particular circumstances. But the relevant concern is not whether a prior restraint rule causes more mischief with speech than it does with property. Instead the concern is to apply sound rules in both areas. Toward that end, the rules developed in conjunction with the First Amendment should be used to reform the impoverished law of takings. The present attitude, which allows full administrative discretion without any judicial accountability, is one of the worst blemishes of the current system.

\section{E. Question Five: Forced Exchanges}

There is one last way to test the limitations of state power under the First and Fifth Amendments. To what extent does the state have the power to single out or select the target of its regula-

${ }^{126}$ United States $v$ Riverside Bayview Homes, Inc., 474 US 121, 127 (1985). Lower courts have relied on Riverside Bayview to stifle challenges to rent control legislation. See, for example, Gilbert $v$ City of Cambridge, 932 F2d 51, 56 (1st Cir 1991).

127 Williamson, 473 US at 199-200. 
tions? The general argument here is that the power to select certain practices or individuals for special government sanctions is an enormous government power that can easily fall prey to abuse. One application of this principle is that regulations do not on their face impose disproportionate burdens on similar activities. A rule that permits the state to impose sanctions on some but not on others, or even one that permits the state to impose heavier sanctions on one than on the other, is a peril against which every legal system should guard.

\section{Selection bias.}

a) Free speech. The importance of this selection bias is evident under the First Amendment, where the modern law imposes very heavy burdens on the state to use content-neutral instead of content-based regulations. Even if the content-neutral regulations are broader in their coverage than content-based regulations, the necessity of imposing burdens on friend and foe alike operates as an implicit but effective check against the abuse of government power. Thus a rule that prohibits all billboard advertisements is less dangerous than one that allows billboards for all purposes, save political campaigns, which in turn is far less dangerous than one that permits billboards to be used only by major political parties, or even by Democrats and not Republicans, or the reverse.

The key is that the total level of speech permitted is of less importance than the mix of speech allowed. ${ }^{128}$ We would rather have a system in which both sides (of a two-sided issue) could speak with two units each than a system in which one side could speak with ten units of speech and the other none. The constitutional theme becomes distortion and imbalance, and content-based distinctions that go to the merits of the ideas expressed are prime examples of the problem.

b) Takings. The same question of political abuse and discretion can arise in connection with the regulation of property and economic liberties. As before, the power to select certain businesses or firms for regulation is easily abused by the political system. A rule that would subject margarine to heavier taxes than butter is one that gives a competitive advantage to the latter over

${ }^{128}$ See Stone, $25 \mathrm{Wm} \&$ Mary L Rev at 197-200 (cited in note 29). 
the former. ${ }^{129}$ A rule that bans plastic milk containers while allowing paper ones is subject to the same criticism. ${ }^{130} \mathrm{~A}$ law that allows a zoning board selectively to designate certain parcels of land as large-lot residential land and then to designate neighboring plots of land as commercial land carries with it the same risk. ${ }^{131}$ In takings cases, there is some language suggesting that disproportionate impact will require the state to provide compensation for the property that it has taken. ${ }^{132}$ But the case law has easily evaded its lofty rhetorical standard, and has sanctioned facially non-neutral government regulations that are ripe for abuse.

\section{Taxation.}

The difference in how speech and takings law treat selection bias can be most conveniently seen if we pay attention to one particular form of government action-taxation. The taxation of newspapers, for example, could present a clear collision between the claims of free speech and the claims of government. Within a strongly libertarian world, the initial impulse is to say that institutions remain free only if they are not subject to tax at all. The usual libertarian formulation is that obligations are imposed upon parties to prevent the use of force, the commission of fraud, or the breach of promise. Taxation is premised on none of these rationales, and should therefore be illegal.

The point is not without historical precedent, for the rhetoric of free trade has on occasion been used by judges to excuse interstate commerce from all sorts of state taxation. ${ }^{133}$ Over time, however, this "libertarian" position has been repudiated in favor of the view that state taxation of interstate commerce cannot be imposed on a discriminatory basis, ${ }^{134}$ but can be imposed on a nondiscrimi-

${ }^{129}$ See McCray v United States, 195 US 27 (1904) (affirming the legislature's prerogative to tax margarine, but not butter).

${ }^{130}$ Minnesota $v$ Clover Leaf Creamery Co., 449 US 456 (1981) (affirming state's right to distinguish between containers for environmental purposes).

131 See Penn Central, 438 US 104 (landmark designation). See also note 83.

${ }^{132}$ See, for example, Armstrong $v$ United States, 364 US 40, 49 (1960) (The Takings Clause "was designed to bar Government from forcing some people alone to bear public burdens which, in all fairness and justice, should be borne by the public as a whole.").

133 Freeman $v$ Hewit, 329 US 249, 252 (1946) ("state is also precluded from taking any action which may fairly be deemed to have the effect of impeding the free flow of trade between states"); Spector Motor Service v O'Connor, 340 US 602, 610 (1951) (federal privilege of carrying on interstate commerce free from state taxation).

134 See Complete Auto Transit, Inc. v Brady, 430 US 274, 287-89 (1977). For an exhaustive historical account of the subject, see Walter Hellerstein, State Taxation of Interstate Business: Perspectives on Two Centuries of Constitutional Adjudication, 41 Tax 
natory basis. This same approach is surely correct for speech and takings law as well.

Thus First Amendment doctrine should take its cue, as indeed it has, from the cases regulating state taxation of interstate commerce. The basic principle is that the tax system works on a benefit theory of taxation, whereby the burdens associated with running a complex society are distributed pro rata to those institutions that benefit from its operations. The ability to pay the tax is irrelevant to the analysis. Protected by an antidiscrimination rule that covers all businesses, a newspaper that is subject to a tax has scant reason to complain, because the services provided from the taxes collected are equal or greater in value to the money surrendered to pay for them. Any nondiscriminatory system of taxation-of which flat taxes are the best candidate-should yield a net benefit to the newspaper taxed. Although the First Amendment has no explicit "just compensation" language that allows for forced exchanges beneficial to the taxed party, but imposed by the state, the eminent domain approach carries over to this situation, even if not formally acknowledged as such, in the cases.

The situation becomes more clouded when taxation is allowed to serve redistributive as well as protective ends, as in the welfare state. Then newspapers, along with all other taxed entities, could be systematically hurt by the tax, which then could be attacked on the ground that the costs imposed are an impediment to speech. This argument has been rejected, apparently without a struggle, on the ground that newspapers are not singled out for special treatment, and therefore obtain protection by anonymity: The resistance that others display to increased taxes protects newspapers against special oppression by the state, and hence against abuse. While it is quite likely that governments are willing to tax the press out of business, it is unlikely that they will set taxes to drive all businesses into bankruptcy. The protection afforded by the nondiscrimination rule may deviate from what is required by theories of optimal taxation, but it does afford important protection against invidious taxation by the state.

The litigated cases of taxation under the First Amendment are not concerned with the question of differential taxation rates between the press and other institutions. Instead they address the question of differential taxation among members of the press. What is instructive about this line of cases is that it develops a

Lawyer 37 (1987). For my views, see Richard A. Epstein, Bargaining with the State ch 9 (Princeton, forthcoming 1993). 
powerful argument for the use of flat taxation across firms, which has powerful application to the general question of taxation under the eminent domain power. In Grosjean v American Press Co. ${ }^{135}$ the Supreme Court struck down a license tax, equal to two percent of gross receipts, that was levied only against publications in the state whose weekly circulation was in excess of $20,000 .{ }^{136}$ At one level, the case was easy, for there was ample information in the record that the tax assumed this form because Senator Huey Long and his state henchmen wished to attack the major papers in the state that had criticized him. But the tax was also suspect on structural grounds, because it singled out some papers for special treatment. The Court relied on both rationales to strike down the tax, avoiding the question of whether the facial discrimination within the class was sufficient to condemn the class. ${ }^{137}$

The structural issue was fairly raised in Minneapolis Star \& Tribune Co. $v$ Minnesota Commissioner of Revenue, ${ }^{\mathbf{1 3 8}}$ where the use tax in question was imposed on the print and ink used by all newspapers, with a $\$ 100,000$ exemption per paper. ${ }^{139}$ The Minneapolis Star attacked the tax for its discriminatory impact, noting that it bore the disproportionate brunt of the tax: only eleven out of 388 papers in the state paid any tax at all, and among that eleven, over two-thirds of the total tax $(\$ 608,634$ out of $\$ 893,355)$ was paid by the Star alone. ${ }^{140}$ The case raised none of the motive issues that clouded the legal question in Grosjean, ${ }^{141}$ and the Court struck down the tax.

The Court noted first that general economic regulations applicable to other business-for example, the antitrust laws or the National Labor Relations Act-could unquestionably be applied to the press. ${ }^{142}$ But the Court then noted that the special use tax on print and ink, with its special exemption, was nowhere duplicated in the Minnesota tax code. ${ }^{143}$ The tax was a form of "special taxation" that "[could not] stand unless the burden [was] necessary to achieve an overriding governmental interest."144 Thus the tax

\footnotetext{
135297 US 233 (1936).

${ }_{136} \mathrm{Id}$ at 240.

137 Id at 250-51.

138460 US 575 (1983).

${ }^{139}$ Id at 578 .

140 Id.

141 Id at 580.

142 Id.

143 Id at 582.

144 Id.
} 
failed for two reasons: First, there was no reason to separate the press from the general system of taxation. Second, within the class of newspapers, there was no reason to impose a differential burden on the Star. The Court recognized that it was difficult to trace the economic consequences of any tax, and that, for all it knew, this tax might benefit newspapers relative to everyone else. But it found that safety necessitated that this tax conform with the others, both within the industry and across industries. ${ }^{145}$

In short, the state had a compelling interest in collecting revenue which justified imposing a tax, but not for imposing a tax of this form. "If the real goal of this tax is to duplicate the sales tax, it is difficult to see why the State did not achieve that goal by the obvious and effective expedient of applying the sales tax." ${ }^{146}$ The Court was quite suspicious of the unequal distribution of the tax across members of the press. The Court's language is worth quoting in full:

Whatever the motive of the legislature in this case, we think that recognizing a power in the State not only to single out the press but also to tailor the tax so that it singles out a few members of the press presents such a potential for abuse that no interest suggested by Minnesota can justify the scheme. It has asserted no interest other than its desire to have an "equitable" tax system. The current system, it explains, promotes equity because it places the burden on large publications that impose more social costs than do smaller publications and that are more likely to be able to bear the burden of the tax. Even if we were willing to accept the premise that large businesses are more profitable and therefore better able to bear the burden of the tax, the State's commitment to this "equity" is questionable, for the concern has not led the State to grant benefits to small businesses in general. And when the exemption selects such a narrowly defined group to bear the full burden of the tax, the tax begins to resemble more a penalty for a few of the largest newspapers than an attempt to favor struggling smaller enterprises. ${ }^{147}$

The point can be made more simply. Whatever revenue target the state wishes to achieve under its sales tax can be achieved by a flat tax across all firms in all industries, without any possibility of

\footnotetext{
14 Id at 585.

${ }_{116}$ Id at 587-88.

147 Id at 591-92 (footnotes omitted).
} 
political abuse. Arguments in this form, however, apply not only to enterprises that fall within the scope of the First Amendment, but across the board. To give only the most notorious example, the windfall profits tax was sustained by the Supreme Court in the teeth of an explicit uniformity challenge (Alaskan north-slope oil was taxed differently), which was given the typically low standard of review that has been applied to economic matters, regardless of which clause of the Constitution they arise under. ${ }^{148}$ But in this situation, it is difficult to figure out any sensible justification for the differential tax treatment, given that subsidies distort choices in economic markets in the same way they do in the market for speech and ideas. There are no special social costs involved in the production of oil (that is, those costs which cannot be handled by direct control of pollution), and ability to pay is irrelevant in the larger economic context as in the speech case. Similarly, it is beside the point to observe that the tax may be passed on to consumers or back to suppliers, for a flat tax surely achieves that result while sparing the court the impossible economic inquiry of tracing out the incidence of the tax burden. ${ }^{149}$

Point by point, then, the intellectual case against all forms of special taxation is identical in all its particulars to those developed by Justice O'Connor in Minneapolis Star. Unless there is some reason, of which I am unaware, why the modern preoccupations with baselines and just initial entitlements alter the results, there seems to be no reason why the arguments in Minneapolis Star should not be used to strike down the industry-specific special taxes that litter the present landscape.

Can the argument be carried still one step further? One way to look at the tax in Minneapolis Star is that it was a system of progressive taxation, in which most newspapers paid no tax, and the largest ones paid over four percent for print and ink costs in excess of $\$ 100,000$. Surely the outcome in the case would have been identical if there had been a two percent tax on print and ink purchases between $\$ 100,000$ and $\$ 250,000$. In essence, what the Court has said is that progressive taxation on different members of the press is unconstitutional under the First Amendment because of the differential burdens that it imposes. Why does the same argument not apply with respect to a progressive tax generally? So long as the state can meet its budgets generally, then there is no

\footnotetext{
${ }^{148}$ United States v Ptasynski, 462 US 74 (1983).

149 For a more extensive development of this point, see Epstein, Takings at 290-92 (cited in note 2).
} 
reason why it should not adopt that form of tax which is least capable of abuse, and most amenable to judicial supervision to reach its goals.

\section{Reconciling the Welfare State with Economic Liberties}

Now we reach the crux of the difference between private property and economic liberties on the one hand, and freedom of speech on the other. There is, as Minneapolis Star tells us, no case for income redistribution within the domain of speech, and indeed strong reasons to oppose it. But the same argument cannot be made with the same force with regard to income redistribution in general.

The case against income redistribution must come to grips with the common perception-the only perception that makes charitable assistance to the poor intelligible-that a dollar of income is worth more to a poor person than to a rich one. It can only overcome that perception by showing that the ostensible gains from redistribution are wholly outweighed by the manifold practical obstacles to effective redistribution, and by the unfortunate incentive effects for the creation of wealth that redistribution creates. It is very clear, notwithstanding the mythic significance that some attach to it, ${ }^{150}$ that Lochner did not stand for the proposition that all forms of income redistribution and welfare measures were prohibited, if only because these were routinely upheld by the Court against all forms of challenges before Lochner was decided in 1905 , and before it was overthrown after $1937 .^{151}$

The question thus arises whether the lessons on disproportionate impact and discriminatory taxation applied with such diligence can be carried over into the welfare state, where by definition some form of income and wealth redistribution is routinely allowed, notwithstanding the explicit anti-redistributive language of the Takings Clause. I think that this reconciliation can take place, and on grounds that should be able to draw the consent of liberals and conservatives alike. The outline of the compromise, which I have

${ }^{130}$ See, for example, Sunstein, 87 Colum L Rev 873 (cited in note 1).

151 See, for example, Bell's Gap R.R. Co. v Pennsylvania, 134 US 232 (1890). On the breakdown of the limitations on taxation, see Clyde E. Jacobs, Law Writers and the Courts (California, 1954). Note that the tax in Pollock v Farmers' Laan \& Trust Co., 157 US 429 (1895), was also progressive, but was not struck down on that ground. See also New York Trust Co. v Eisner, 256 US 345 (1921) (sustaining a progressive estate tax). 
proposed before, ${ }^{152}$ is that the state can redistribute as much as it likes from rich to poor so long as it does so through general revenue taxes. There is of course some room for redistribution even with the flat tax on income. This proposal waives all objections to progressive taxation, but insists only that the remainder of the structure protecting private property and economic liberties be respected and enforced. If the state wants to provide individuals with below market housing, then it can rent the units from private owners at market levels, relet them to poorer citizens at below market levels, and make up the difference by a tax on general revenues. The program thus places the cost of this public good (as redistribution has become) on the public at large, where in fairness and justice it belongs. The public at large has decided that the change is appropriate and thus should foot the bill for initiatives that the landowner may well have opposed. What can be done with rent control can be done with zoning, with specialized facilities for the handicapped, with subsidized health insurance for AIDS victims, and with educational vouchers for the poor. If one can make a gift transaction to the poor, it is always possible to fund it out of general revenues.

The justification for this approach has thus far been phrased in the distributive language used by Justice Black in his well known quotation from Armstrong. ${ }^{153}$ But it bears repetition that the shift in financing procedure has vast implications for both democratic theory and economic efficiency. As regards the former, it encourages responsible behavior by citizens, who are no longer in the position to vote revenues for group A out of the pocket of group $B$. The tendency to play special interest politics will be eased by the requirement that participation entails the right to control but also entails the obligation to bear imposed obligations with one's fellow citizens. Even staunch defenders of republican virtue should prefer a responsible citizenry to the powerful one, and this reconciliation of the Takings Clause with the welfare state achieves just that end.

The efficiency argument is every bit as powerful. The nature of the programs that will be funded will differ as the method for funding those programs changes. The situation in which the voters at large can shift all the costs of running the welfare state to a tiny

152 See Richard A. Epstein, Takings: Of Maginot Lines and Constitutional Compromises, in Ellen Frankel Paul and Howard Dickman, eds, Liberty, Property, and the Future of Constitutional Development 173 (SUNY, 1990).

${ }^{153}$ See note 132. 
fraction of the population contains a built-in externality: one group decides, and another group pays. The usual economic conclusion about externalities applies: too much of the good will be demanded relative to other goods that might be purchased, a conclusion that applies even when one good is aid to the poor and the other is repaving the public streets. Correct voting procedure neutralizes some of the externalities that are otherwise implicit in the current system that invites disproportionate funding, not only of welfare payments, but of any imaginable government expenditure (whether or not pure public goods). A system that more accurately measures the public sympathy and support for various programs is surely preferable to one that so skews the inquiry that the level of production of welfare payments, relative to other goods, is excessive. The total level of goods and services should increase as well, which increases the size of the base available for redistributive purchases. Even a post-New Deal legislature, however aware of the evils of common law baselines, can only redistribute through the political process what is produced through the economic one.

Finally the proposal places a limitation on the nature and kinds of redistribution that are feasible: There is redistribution along one dimension only, from rich to poor, for it is only along that line that one can assume that a single unit of wealth means more to the recipient than it does to the donor. Gone are the days therefore of the inveterate agricultural subsidies that benefit corporate farmers at the expense of poor ghetto dwellers, and gone are the days when exclusionary zoning can keep poor people out of affluent suburbs. If redistribution of wealth from rich to poor is the goal, then a court can scrutinize the program in question to see that there is a reasonable means-end connection. The welfare state is thus reconcilable with the Bill of Rights in an imperfect but powerful way. It remains to see whether the inveterate judicial temperament keeps us chained to a jurisprudence of economic liberty that has stifled the power and initiative of this country for the last fifty years, indeed longer. 
